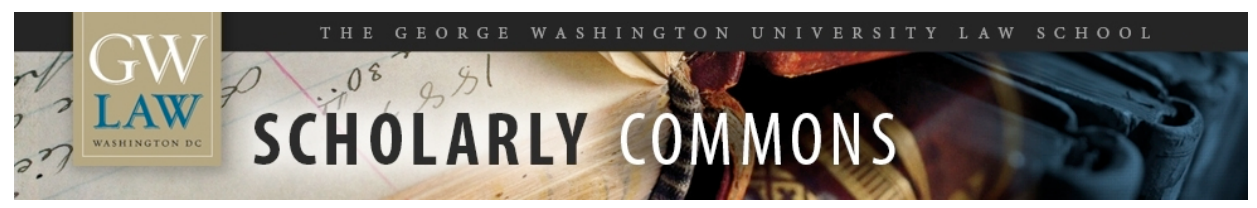

The Rocky Road to Energy Dominance: The Executive Branch's Limited Authority to Modify and Revoke Withdrawals of Federal Lands from Mineral Production

Robert L. Glicksman

Hillary M. Hoffman

Follow this and additional works at: https://scholarship.law.gwu.edu/faculty_publications 


\title{
The Rocky Road to Energy Dominance: The Executive Branch's Limited Authority to Modify and Revoke Withdrawals of Federal Lands from Mineral Production
}

\author{
Hillary M. Hoffmann ${ }^{*} \&$ Robert L. Glicksman ${ }^{* *}$ \\ 33 Geo. J. EnVtL L., Issue \# 2 (forthcoming)
}

Abstract

The Trump Administration's implementation of its America First Energy Plan, whose goal is achieving U.S. "energy dominance," has relied heavily upon public mineral development. Mineral development on federal lands is largely governed by statute. The statutory legal mechanisms by which the Executive Branch can "open" or "close" an area of federal lands to mineral development, whether onshore or offshore, are withdrawal, modification, and revocation.

The Federal Land Policy and Management Act (FLPMA) and the Outer Continental Shelf Lands Act (OCSLA) are the primary statutes that govern onshore and offshore mineral development on over 2 billion acres of federal lands. Both FLPMA and OCSLA authorize withdrawals, which the Executive can use to place federal lands off limits to mineral development. FLPMA also authorizes modifications and revocations, which can remove constraints on such development. The Trump Administration has relied on both statutes in its quest to expand the areas that are available for private mineral disposition through modification or revocation of withdrawals by prior administrations.

The authority provided by FLPMA and OCSLA to determine the availability of federal lands for mineral development is subject to a series of substantive and procedural constraints. Because it regards those constraints as undesirable shackles on the implementation of its mineral development policies, and consistent with its expansive view of Executive Branch power in almost all contexts, the Administration has not been content to rely on statutory authorization to modify and revoke development-precluding withdrawals. Instead, it has also invoked nonstatutory, implied or inherent authority to open vast areas of federal lands to oil and gas, coal, and other mineral development.

The paucity of judicial precedent governing the parameters of statutory and nonstatutory Executive Branch authority to reopen lands previously placed off limits to mineral development raises significant questions about the legality of the Administration's efforts to alter the status of protected lands and resources. Although the Administration apparently regards downsizing or revocation of withdrawals by previous administrations as a quick and effective way to open up vast new acreage to mineral development, the legal basis for its actions is tenuous at best.

This Article examines both statutory and nonstatutory mechanisms for determining the availability of federal onshore and offshore lands for uses such as mineral exploration and

\footnotetext{
* Professor of Law, Vermont Law School; Visiting Robert H. McKinney Family Chair in Environmental Law, Indiana University Robert H. McKinney School of Law (Fall 2020).

** J.B. \& Maurice C. Shapiro Professor of Environmental Law, The George Washington University Law School.
} 


\section{Draft: Please do not cite without authors' permission}

To be published at 33 GEO. ENVTL. L. REV., IssuE \# 2

development. It identifies the constraints that FLPMA and OCSLA impose on revocation or modification of previous withdrawals. It also explores the parameters of nonstatutory Executive mineral disposition authority and assesses the legality of the significant Trump Administration withdrawal modification and revocation efforts to date. It concludes that Congress has eliminated any implied or inherent withdrawal, revocation, or modification authority that may once have existed. It also finds that the most prominent and controversial of the Trump withdrawal modifications and revocations exceeded the authority the Executive Branch retains under FLPMA and OCSLA. As a result, that the Trump Administration's unauthorized pursuit of energy dominance should result in judicial invalidation.

\section{Outline}

Introduction

I. The History of Withdrawals and Revocations Prior to OCSLA and FLPMA

A. 1800-1900: Acquisition, Disposal, and the Pursuit of Manifest Destiny

B. 1900-1950: Transitioning into Retention and Conservation, and Growing Questions About Withdrawal and Revocation Authority

II. Congressional attempts to Organize the Chaos: the Legislative History of the Outer Continental Shelf Lands Act and the Federal Land Policy and Management Act

A. Offshore Public Mineral Development and OCSLA

1. The Origins of the Outer Continental Shelf Lands Act

2. OCSLA's Limited Delegation of Presidential Withdrawal Authority

B. Onshore Public Mineral Development and FLPMA

1. FLPMA's Legislative History - the Public Lands Law Commission Report

2. FLPMA's Limited Delegation of Secretarial Withdrawal, Modification and Revocation Authority

III. Chaos Further Resolved: The Demise of the Nonstatutory Presidential Practice of Making, Modifying or Revoking Prior Withdrawals and Congress's Limited Delegations of Authority in OCSLA and FLPMA

A. Nonstatutory Presidential Revocations on Federal Lands: A Relic of the Past

B. What Remains: Limited Executive Branch Authority to Make, Modify, or Revoke Withdrawals of Federal Lands Under OCSLA and FLPMA Conclusion 


\section{Draft: Please do not cite without authors' permission}

To be published at 33 GEO. ENVTL. L. REV., ISSUE \# 2

\section{INTRODUCTION}

The Trump Administration's energy legacy has included numerous steps to revoke, curtail, or alter the actions of previous administrations withdrawing areas of federally owned land from exploration and development of minerals, particularly oil, gas, and coal. The Trump Administration made its zeal for achieving what it later dubbed a quest for "energy dominance"1 clear almost immediately after President Trump took office in January 2017. In March of that year, the President issued an executive order requiring all federal agencies to review actions that "potentially burden the development or use of domestically produced energy resources," particularly fossil fuel and nuclear energy resources."2 The order also directed the Secretary of the Interior to "lift any and all moratoria on Federal land coal leasing activities." 3 This portion of the order was the Trump Administration's response to an Obama-era Secretarial order halting review of new applications for federal coal leases pending the preparation of a programmatic environmental impact statement (EIS) under the National Environmental Policy Act (NEPA). ${ }^{4}$ Within days, Trump's first Secretary of Interior, Ryan Zinke, revoked the Obama Secretarial order, finding that "the public interest is not served by halting the Federal coal program for an extended time, nor is a [programmatic EIS] required to consider potential improvements to the

\footnotetext{
${ }^{1}$ See White House Fact Sheet, President Donald J. Trump Is Unleashing American Energy Dominance, May 14, 2019, https://www.whitehouse.gov/briefings-statements/president-donald-j-trump-unleashing-american-energydominance/; Justin Worland, President Trump Says He Wants 'Energy Dominance.' What Does He Mean?, TIME, June 30, 2017, https://time.com/4839884/energy-dominance-energy-independence-donald-trump/ (noting that President Trump's "energy dominance" agenda included "a slew of initiatives aimed at speeding up production of oil, natural gas and coal .... Trump has described his policies as a dramatic shift in direction from the Obama years, [which he] described ... as 'eight years of hell' that included 'massive job-killing barriers to American energy development."').

${ }^{2}$ Exec. Order No. 13783, Presidential Executive Order in Promoting Energy Independence and Economic Growth, $\S \S 2$ (a) \& (b), 82 Fed. Reg. 16093, 16093 (Mar. 31, 2017). The Order defined burden to mean "unnecessarily obstruct, delay, curtail, or otherwise impose significant costs on the siting, permitting, production, utilization, transmission, or delivery of energy resources." Id. §2(b).

${ }^{3}$ Id. $\S 6,82$ Fed. Reg. 16096.

${ }^{4}$ Secretarial Order No. 3338, Discretionary Programmatic Environmental Impact Statement to Modernize the Federal Coal Program $\S \S 4,5 a(J a n .15,2016)$, https://www.eenews.net/assets/2016/01/15/document_gw_04.pdf.
} 


\section{Draft: Please do not cite without authors' permission}

To be published at 33 GEO. ENVTL. L. REV., ISSUE \# 2

program." Zinke directed the Interior Department's Bureau of Land Management (BLM) “to

process coal lease applications and modifications expeditiously." 6 Two months later, Secretary

of Energy Rick Perry, during the Administration's self-described "Energy Week," singled out the

Obama Administration's "hostility towards coal" as the most important factor in the coal industry's falling fortunes. ${ }^{7}$

Shifting his attention to offshore resources, in April 2017, President Trump initiated an effort to open up submerged lands off the coast of Alaska and in the North Atlantic, which had been withdrawn from oil and gas development by President Obama, using the Outer Continental Shelf Lands Act (OCSLA). ${ }^{8}$ In another executive order, Trump announced a policy of “encourag[ing] energy exploration and production, including on the Outer Continental Shelf, in order to maintain the nation's position as a global energy leader and foster energy security and resilience."9 The order directed the Interior Secretary to consider revising the schedule of proposed oil and gas lease sales so that it included annual lease sales "to the maximum extent permitted by law." 10 The President also ordered the Secretary of Commerce to refrain from

\footnotetext{
${ }^{5}$ Secretarial Order No. 3348, § 4, Concerning the Federal Coal Moratorium (Mar. 29, 2017), https://www.doi.gov/sites/doi.gov/files/uploads/so 3348 coal moratorium.pdf. This order was challenged unsuccessfully. See Citizens for Clean Energy v. U.S. Dep't of the Interior, No. CV-17-30-GF-BMM, 2020 WL 2615527 (D. Mont. May 22, 2020); Citizens for Clean Energy v. U.S. Dep't of the Interior, 384 F. Supp. 3d 1264 (D. Mont. 2019). The district court indicated, however, that "Plaintiffs remain free to file a complaint to challenge the sufficiency of the EA and FONSI and the issuance of any individual coal leases." Citizens for Clean Energy v. U.S. Dep't of the Interior, No. CV-17-30-GF-BMM, 2020 WL 2615527, at*9 (D. Mont. May 22, 2020).

${ }^{6}$ Secretarial Order No. 3348, $\S 5$.

${ }^{7}$ Krysti Shallenberger, Energy Week: Perry Touts All-of-the-Above Strategy in Push for 'Energy Dominance', UTILITY DIVE, June 28, 2019, https://www.utilitydive.com/news/energy-week-perry-touts-all-of-the-above-strategyin-push-for-energy-domi/446052/ (quoting Secretary Perry's assertion that "[ $t]$ hese politically-driven policies driven by a hostility to coal threatens [sic] the reliability and stability of the greatest electrical grid in the world").

${ }^{8}$ Sabrina Shankman, Trump Moves to Lift Offshore Arctic Drilling Ban, But It Might Not Be So Easy, InSIDE CLIMATE NEws, Apr. 28, 2017, https://insideclimatenews.org/news/28042017/doanld-trump-arctic-offshore-drillingban-obama-executive-order; Coral Davenport, Obama Bans Drilling in Parts of the Atlantic and the Arctic, N.Y. TIMES, Dec. 20, 2016), https://www.nytimes.com/2016/12/20/us/obama-drilling-ban-arctic-atlantic.html.

${ }^{9}$ Exec. Order No. 13795, Implementing an America-First Offshore Energy Strategy, §§ 2, 82 Fed. Reg. 20815, 20815 (May 3, 2017).

${ }^{10} I d . \S 3(\mathrm{a})$.
} 


\section{Draft: Please do not cite without authors' permission}

To be published at 33 GEO. ENVTL. L. REV., IssuE \# 2

designating or expanding National Marine Sanctuaries and to review all designations of those Sanctuaries and of marine national monuments under the Antiquities Act of 1906 to assess, among other criteria, "the opportunity costs associated with potential energy and mineral exploration and production" inside the previously protected marine monuments. ${ }^{11}$ With alacrity, Interior Secretary Zinke issued an order to implement the "America-First Offshore Energy Strategy," 12 which directed the Interior Department's Bureau of Ocean Energy Management (BOEM) to "[i]mmediately initiate development" of a new five-year leasing program."13

The Administration also quickly took other actions to remove constraints on energy development put in place by previous administrations. In the same month that he sought to accelerate offshore oil and gas exploration, President Trump issued an executive order directing the Interior Secretary to conduct a review of all presidential designations or expansions of national monuments under the Antiquities Act since January 1996, "where the designation after expansion covers more than 100,000 acres, or where the Secretary determines that the designation or expansion was made without adequate public outreach and coordination with relevant stakeholders and the effects on surrounding lands and communities." ${ }^{14}$ The ostensible purpose of the review was to assess whether these designations or expansions conform to the executive order's pronouncement that "[d]esignations should be made in accordance with the requirements and original objectives of the [Antiquities] Act and appropriately balance the protection of landmarks, structures, and objects against the appropriate use of Federal lands and

\footnotetext{
${ }^{11}$ Id. $\S 4$ (a)-(b). The Antiquities Act is codified at 54 U.S.C. $\S \S 32301-32303$.

${ }^{12}$ Secretarial Order No. 3350, America -First Offshore Energy Strategy (May 1, 2017),

https://www.doi.gov/sites/doi.gov/files/press-release/secretarial-order-3350.pdf.

${ }^{13} \mathrm{Id} . \S 4 \mathrm{a}(1)$.

${ }^{14}$ Exec. Order No. 13792, Review of Designations Under the Antiquities Act, § 2, 82 Fed. Reg. 20429, 20429 (May 1, 2017).
} 


\section{Draft: Please do not cite without authors' permission}

To be published at 33 GeO. ENVTL. L. ReV., Issue \# 2

the effects on surrounding lands and communities." ${ }^{15}$ The order singled out the Bears Ears National Monument, ${ }^{16}$ which President Obama had reserved and withdrawn from mineral entry, location, sale, new leasing, or other disposition, ${ }^{17}$ requiring the Secretary to provide an interim report to the President and other administration officials containing recommendations on the future fate of that monument. ${ }^{18}$

Six weeks later, Secretary Zinke issued his interim report recommending modification of the boundaries of Bears Ears. ${ }^{19}$ President Trump followed Zinke's recommendation and signed a proclamation "modifying" Bears Ears in December 2017. ${ }^{20}$ In the Proclamation, President Trump declared "it is in the public interest to modify the boundaries of the monument to exclude from its designation and reservation approximately 1,150,860 acres of land that I find are unnecessary for the care and management of the objects to be protected within the monument."21 He therefore proclaimed that "the boundaries of the Bears Ears National Monument are hereby modified and reduced" accordingly. ${ }^{22}$ Further, he proclaimed that lands excluded from the monument pursuant to the Proclamation would be open to "(1) entry, location, selection, sale, or other disposition under the public land laws and laws applicable to the U.S. Forest Service; (2)

${ }^{15} I d . \S 1$.

${ }^{16} I d . \S 2(\mathrm{~d}), 82$ Fed. Reg. at 20430.

${ }^{17}$ Presidential Proclamation 9558, Establishment of the Bears Ears National Monument, 82 Fed. Reg. 1139 (Dec. 28 , 2016). For a discussion of the history leading up to President Obama's establishment of the Bears Ears National Monument, see Sarah Krakoff, Public Lands, Conservation, and the Possibility of Justice, 53 HARV. CIV. RightS.CIV. LIB. L. REV. 213, 214 (2018).

${ }^{18}$ Exec. Order No. 13792, supra note 14, § 2(d).

${ }^{19}$ Interim Report Pursuant to Executive Order 13792 (June 10, 2017), https://www.scribd.com/document/351066813/Interim-Report-EO-13792.

${ }^{20}$ Presidential Proclamation 9681, Modifying the Bears Ears National Monument, 82 Fed. Reg. 58081 (Dec. 8, 2017).

${ }^{21} I d$. at 58085 .

${ }^{22} I d$. 


\section{Draft: Please do not cite without authors' permission}

To be published at 33 GEO. ENVTL. L. REV., ISSUE \# 2

disposition under all laws relating to mineral and geothermal leasing; and (3) location, entry, and patent under the mining laws." 23

On the same day that he reduced Bears Ears, President Trump issued another proclamation modifying the boundaries of the Grand Staircase-Escalante National Monument, established by President Bill Clinton in $1996 .{ }^{24}$ Like the Bears Ears proclamation, Clinton's Grand Staircase-Escalante designation had withdrawn all lands within that monument to mineral development, preventing the development of a massive coal mine by Andalex Resources. ${ }^{25}$ In an attempt to remove what he saw as a barrier to development of the coal Andalex had pursued two decades earlier, President Trump declared it to be "in the public interest to modify the boundary of the monument to exclude from its designation and reservation approximately 861,974 acres of land that I find are no longer necessary for the proper care and management of the objects to be protected within the monument." 26 The Trump proclamation declared the newly excluded lands open to mineral entry and disposition, and reopened to mineral development several areas that hold some of the largest coal deposits in the western hemisphere. ${ }^{27}$ Trump's two 2017 proclamations shrunk Bears Ears by about eighty-five percent and Grand Staircase by about half,

${ }^{23} I d$.

${ }^{24}$ Presidential Proclamation 6920, Establishment of the Grand Staircase-Escalante National Monument, 61 Fed. Reg. 50223 (Sept. 18, 1996).

${ }^{25}$ Id. Clinton's proclamation stated that:

[a]11 Federal lands and interests in lands within the boundaries of this monument are hereby appropriated and withdrawn from entry, location, selection, sale, leasing, or other disposition under the public land laws, other than by exchange that furthers the protective purposes of the monument. Lands and interests in lands not owned by the United States shall be reserved as a part of the monument upon acquisition of title thereto by the United States.

Id. at 50225. See also Juliet Eilperin, A Diminished Monument, WASH. POST (Jan. 15, 2019), https://www.washingtonpost.com/graphics/2019/national/environment/will-anyone-mine-after-grand-staircaseescalante-reduction-by-trump/.

${ }^{26}$ Presidential Proclamation 6982, Modifying the Grand Staircase-Escalante National Monument, 82 Fed. Reg. 58089, 58093 (Dec. 8, 2017).

${ }^{27} I d$. The Clinton Grand Staircase-Escalante National Monument was estimated to hold 62 billion tons of coal. Jennifer Yachnin, Administration Pushed to Save Coal Deposits, E\&E NEws, Mar. 14, 2019, https://www-eenewsnet.gwlaw.idm.oclc.org/eedaily/2019/03/14/stories/1060127237. 


\section{Draft: Please do not cite without authors' permission}

To be published at 33 GEO. ENVTL. L. REV., ISSUE \# 2

revoking withdrawals covering approximately 1.8 million acres. ${ }^{28}$ Once the revised monument management plans were finalized in February of 2020, it became quite clear that the Administration's motives were to open up previously protected monument lands for oil and gas, uranium, and coal development, along with other previously prohibited activities like high impact off-road vehicle use. ${ }^{29}$

Former Secretary Zinke and his successor, David Bernhardt, have followed the President's lead in expanding private access to energy resources on lands owned or controlled by the federal government at the agency level as well. In doing so, they have increased the rate of oil and gas leasing and federal mineral exploitation since 2017, opening 1.6 million acres of land in the western United States to oil and gas leasing in 2017, and another 2.1 million acres in $2018 .^{30}$ In total, the Trump Administration removed protections on nearly 13.5 million acres of onshore federal public lands in little more than three years, and by April of 2020, the

\footnotetext{
${ }^{28}$ Coral Davenport, Trump Opens National Monument Land to Energy Exploration, N.Y. TIMES, Feb. 6, 2020, https://www.nytimes.com/2020/02/06/climate/trump-grand-staircase-monument.html; Julie Turkewitz, Trump Slashes Size of Bears Ears and Grand Staircase Monuments, N.Y. TIMES, Dec. 4, 2017, https://www.nytimes.com/2017/12/04/us/trump-bears-ears.html. For maps showing the original and redrawn boundaries of the two monuments, see Adam Roy, Map: This Is What Bears Ears Is Losing, BACKPACKER, Dec. 11, 2017; Points to Make in Your Comments on Grand Staircase-Escalante National Monument, SOUTHERN UTAH WILDERNESS ALLIANCE, https://suwa.org/points-make-comments-grand-staircase-escalante-national-monument/ (last visited June 8, 2020).

${ }^{29}$ See BLM Record of Decision and Approved Monument Management Plans for Bears Ears National Monument (Feb. 6, 2020), https://eplanning.blm.gov/epl-frontoffice/projects/lup/94460/20012455/250017011/BLM_ROD_and_Approved_MMPs_for the Indian_Creek_and_Sh ash_Jaa_Units_of BENM_February2020.pdf; BLM Grand Staircase-Escalante National Monument \& KanabEscalante Planning Area Resource Management Plans (Feb. 6, 2020), https://eplanning.blm.gov/epl-frontoffice/eplanning $/$ planAndProjectSite.do? methodName=dispatchToPatternPage\&currentPageId=141292.

${ }^{30}$ Kyla Mandel, Lack of Demand Hasn't Stopped Trump from Opening Tons of Land to Oil and Gas Drilling, THINKPROGRESS, Apr. 12, 2019, https://thinkprogress.org/trump-interior-oil-gas-drilling/. The 2018 amounts were four times the amounts made available for leasing in the final year of the Obama Administration. Id.; Ctr. for W. Priorities, The Oil and Gas Leasing Process on U.S. Public Lands, https://westernpriorities.org/issues/drilling-onpublic-lands/ (last visited Apr. 11, 2020).
} 


\section{Draft: Please do not cite without authors' permission}

To be published at 33 GEO. ENVTL. L. REV., ISSUE \# 2

Administration had offered more than 24 million acres of onshore federal land for oil and gas development. $^{31}$

The federal lands, including offshore submerged lands, have been critical to implementing the goals of Trump's America First Energy Plan, which involves extensive mineral development of all types. ${ }^{32}$ The Plan primarily focuses on oil, natural gas, and coal, although the Administration has paved the way for increased uranium mining and milling in the southwest and also increased mining operations for rare-earth minerals like lithium, which are essential for the development of new energy technologies. ${ }^{33}$ However, the Trump

Administration's somewhat freewheeling approach to opening federal lands to mineral development and encouraging or unburdening the development of these resources has called into question the precise legal basis for its actions. ${ }^{34}$ Courts have resolved some of these questions in recent legal challenges, as indicated below. ${ }^{35}$ The larger matter of how and to what degree the Executive Branch can open federal lands to mineral extraction, however, is fairly clearly

\footnotetext{
${ }^{31}$ Jenny Rowland-Shea \& Maryellen Kustin, A 13.5 Million Acre Lie, CTR. FOR AMERICAN PROGRESS, Mar. 20, 2019, https://www.americanprogress.org/issues/green/news/2019/03/20/467548/13-5-million-acre-lie/.

32 White House Fact Sheet, President Donald J. Trump is Ending the War on American Energy and Delivering a New Era of Energy Dominance (Oct. 23, 2019), https:/www.whitehouse.gov/briefings-statements/president-donaldj-trump-ending-war-american-energy-delivering-new-era-energy-dominance/.

${ }^{33}$ Rowland-Shea \& Kustin, supra note 31 ("Numbers for new acres leased and new leases issued during the year have continued to increase, up 117 percent for new acres leased during the year and up 156 percent for new leases issued since FY 2016.”); Ernest Scheyder, Lithium Americas Moves Closer to Nevada Mine Approval, REUTERS (Jan. 20, 2020), https://www.reuters.com/article/us-usa-mining-lithium-americas/lithium-americas-moves-closer-tonevada-mine-approval-idUSKBN1ZJ1WP; U.S. Dep't of Commerce, A Federal Strategy to Ensure Secure and Reliable Supplies of Critical Minerals (June 4, 2019), https://www.commerce.gov/news/reports/2019/06/federalstrategy-ensure-secure-and-reliable-supplies-critical-minerals; Chris D’Angelo, Fears Mount That Trump Will Green-light Uranium Mining Near Grand Canyon, HufFPost, June 5, 2019, https://www.huffpost.com/entry/uranium-mining-grand-canyon-ban_n_5cf848cde4b0e63eda953c65. As recently as June 2019, the Commerce Department released a strategy calling for faster permitting for mining operations and a "thorough review" of all mineral withdrawals on federal lands. U.S. Dep't of Commerce, A Federal Strategy to Ensure Secure and Reliable Supplies of Critical Minerals, June 4, 2019, https://www.commerce.gov/news/reports/2019/06/federal-strategy-ensure-secure-and-reliable-supplies-criticalminerals.

${ }^{34}$ See Exec. Order No. 13783, supra note 2, §§ 2(a) \& (b).

${ }^{35}$ See National Mining Ass'n v. Zinke, 877 F.3d 845, 856 (9th Cir. 2016); League of Conservation Voters v. Trump, 363 F. Supp. 3d 1013, 1031 (D. Alaska 2019); see infra notes 236, 336-337 and accompanying text.
} 


\section{Draft: Please do not cite without authors' permission}

To be published at 33 GEO. ENVTL. L. REV., ISSUE \# 2

delineated in the respective statutes Congress has enacted over the past fifty years regulating mineral development on federal lands, which cast doubt on the validity of the Trump Administration's actions.

Two statutes guide the development of these mineral resources on federal lands in the modern era, OCLSA ${ }^{36}$ and the Federal Lands Policy and Management Act (FLPMA), ${ }^{37}$ although they are somewhat recent additions to the library of public lands laws. Throughout the nineteenth century and into the twentieth century, Congress passed a multitude of statutes that encouraged the use and development of federal lands and resources to help aid western settlement and economic development, including mineral-bearing lands. ${ }^{38}$ At first, the federal policy was to convey the surface estate and retain the mineral interest, but in the late nineteenth century, and especially after the enactment of the General Mining Law in 1866, and its amendment in 1870 and $1872,{ }^{39}$ disposal of even the mineral-bearing lands for the purpose of mineral development became part of the codified federal policy. ${ }^{40}$ Although many of these statutes have been repealed, some of them remain in effect, which complicates the management of federal lands.

Historically, Congress was willing to allow coastal states to control offshore mineral development and the Executive Branch to control disposition of onshore mineral bearing lands, but this willingness faded by the mid-century mark. ${ }^{41}$ In 1953, Congress resolved the questions

\footnotetext{
${ }^{36}$ Outer Continental Shelf Lands Act, 43 U.S.C. $\S \S 1331-1356 b$ (2018).

${ }^{37}$ Federal Land Policy \& Management Act, 43 U.S.C. $\S \S 1701-1787(2018)$.

${ }^{38}$ Sylvia L. Harrison, Disposition of the Mineral Estate on United States Public Lands: A Historical Perspective, 10 PUB. LAND L. REV. 131, 141 (1989) (noting that early to mid-nineteenth century "enactments resulted in the conveyance of public lands to private individuals and companies, [but] most contained some provision for retention of a portion of the public mineral estate for public purposes").

${ }^{39}$ See 1 George Cameron Coggins \& Robert L. Glicksman, Public Natural Resources LaW $§ 2: 5$ (2d ed. 2007) (describing the 1872 statute as amending and codifying the two earlier enactments).

${ }^{40}$ Harrison, supra note 38, at 147; see 1 CoGGINS \& GLICKSMAN, supra note 39, §§ 2:2 to 2:9 (describing the "Age of Disposition" between 1787 and 1934).

${ }^{41}$ See 1 COGGINS \& GLICKSMAN, supra note 39, $\S \S 2: 10$ to2:15 (describing the onset of the "Age of Conservation" between 1934 and 1964). Congress had begun to limit access to and development of federal lands and resources for certain non-mineral uses before mid-century in statutes such as the Taylor Grazing Act of 1934, 43 U.S.C. $\S \S 315$ to
} 


\section{Draft: Please do not cite without authors' permission}

To be published at 33 GEO. ENVTL. L. REV., ISSUE \# 2

of offshore ownership and jurisdiction by passing OCSLA, which asserted the federal government's ownership and management authority over mineral resources in the outer continental shelf, adding a subsequent declaration of national policy in 1978 that these resources be developed consistent with certain "environmental safeguards." ${ }^{42}$ In adopting FLPMA in 1976, Congress declared the beginning of a new era of onshore federal land management, focused on retention of federal lands and more cautious and purposeful management of their varied resources, including management requirements that protect the quality of "environmental ... values. ${ }^{43}$

Together, these two statutes now regulate mineral development on 1.75 billion acres of submerged offshore lands (OCSLA) and 700 million acres of onshore federal lands (FLPMA) ${ }^{44}$ Although numerous other statutes guide and constrain mineral development in various ways, these are the threshold laws that determine which federal lands will be open, or closed, to mineral development, and, if closed, whether temporarily or permanently. ${ }^{45}$ Both OCLSA and FLPMA delegate authority to the Executive Branch to withdraw offshore and onshore federal lands containing mineral resources from the operation of the statutes that otherwise allow these activities, such as the General Mining $\operatorname{Law}^{46}$ and the Mineral Leasing Act. ${ }^{47}$ OCSCLA does not

\footnotetext{
$315 \mathrm{r}$ (ending the use of public lands as an open commons for grazing). See 1 CoGGINS \& GLICKSMAN, supra note $39, \S 2: 14$.

4243 U.S.C. $\S \S 1332,1341(a)$.

${ }^{43}$ Id. $\S 1701(\mathrm{a})(8)(2014)$.

${ }^{44}$ G. Kevin Jones, Understanding the Debate over Congressionally Imposed Moratoria on Outer Continental Shelf Oil and Gas Leasing, 9 TEMP. ENVTL. L. \& TECH. J. 117, 122 (1990) (discussing scope of Interior Secretary James Watt's opening of nearly all of BOEM submerged lands to oil and gas during first years of Reagan Administration); Stefanie L. Burt, Who Owns_the Right to Store Gas: A Survey of Pore Space Ownership in U.S. Jurisdictions, 4 Joule: DUQ. ENERGY \& ENVTL. L.J. 1, 10 (2016).

4543 U.S.C. $\S 1341(\mathrm{a}) ; 43$ U.S.C. $\$ 1714(\mathrm{a})$.

${ }^{46}$ Sess. 2, ch. 152, 17 Stat. 91-96 (1872) (codified as amended in scattered sections of 30 U.S.C.).

4730 U.S.C. $\S \S 181-287$ (2018).
} 


\section{Draft: Please do not cite without authors' permission}

To be published at 33 GEO. ENVTL. L. REV., ISSUE \# 2

grant the Executive any power to revoke prior offshore withdrawals. ${ }^{48}$ FLPMA does give the Secretary of Interior revocation authority, but the Secretary's discretion is limited. ${ }^{49}$

Recognition of these limits has featured prominently in the limited judicial opinions analyzing the scope of Executive revocation authority under FLPMA ${ }^{50}$ Thus, while FLPMA authorizes the Secretary of Interior to withdraw federal lands containing mineral resources from the operation of the mineral development statutes, on a temporary or permanent basis, it also limits the Executive's authority to revoke, modify or otherwise affect previous withdrawals. When viewed together with OCSLA's limited, one-way delegation of authority to withdraw offshore mineral-bearing lands from development, it is clear that Congress's overarching intent in crafting these modern federal land and resource management laws was to (1) repeal nonstatutory Executive Branch withdrawal, modification, and revocation authority, (2) carefully delineate Executive branch authority to reopen federal lands to resource exploitation through revocation of previous constraints on development, and (3) codify a preference for federal retention of lands and mineral resources, unless Congress has spoken or acted to mandate or authorize disposition. $^{51}$

This Article examines the FLPMA and OCSLA mechanisms authorizing withdrawal of federal onshore and offshore lands and the constraints both statutes impose on revocation or

\footnotetext{
${ }^{48}$ League of Conservation Voters v. Trump, 363 F. Supp. 3d 1013, 1031 (D. Alaska 2019).

49 See 43 U.S.C. § 1714(a); see also Robert L. Glicksman, Sustainable Federal Land Management: Protecting Ecological Integrity and Preserving Environmental Principal, 44 TULSA L. REV. 147, 160 (2008) [hereinafter Glicksman, Ecological Integrity] (characterizing FLPMA as "a movement away from the tilt toward commodity production ... and toward the protection of environmental values").

${ }^{50}$ See infra Parts IIB, IIIB.

${ }^{51} 43$ U.S.C. § 1341(a); 43 U.S.C. § 1714(a); see George Cameron Coggins \& Doris K. Nagel, "Nothing Beside Remains": The Legal Legacy of James G. Watt's Tenure as Secretary of the Interior on Federal Land Law and Policy, 17 B.C. ENVTL. AfF. L. REV. 473, 505 (1990) [hereinafter Coggins, Watt]; see also Lujan v. Nat'l Wildlife Fed'n, 497 U.S. 871, 877 (1990) (referring to FLPMA's public land and resource retention policy); Nat'l Wildlife Fed'n v. Burford, 676 F. Supp. 271 (D.D.C. 1985), reconsideration denied, 676 F. Supp. 280 (D.D.C. 1986), $a f f ' d, 835$ F.2d 305 (D.C. Cir. 1987), reh'g denied, 844 F.2d 889 (2d Cir. 1988) (enjoining termination of protective classifications and withdrawal revocations on 170 million acres of public lands).
} 


\section{Draft: Please do not cite without authors' permission}

To be published at 33 GEO. ENVTL. L. REV., IssuE \# 2

modification of such withdrawals. Part I provides a brief history of onshore and offshore executive withdrawals and revocations prior to the enactment of OCSLA and FLPMA. Part II explores the reasons why Congress chose to circumscribe Executive Branch authority to withdraw and revoke prior withdrawals in both areas, drawing on the legislative history, the enacted text, and judicial interpretations of both statutes. Part III focuses on the resulting parameters of Executive withdrawal authority, concluding that there is no longer any nonstatutory withdrawal, revocation, or modification authority after FLPMA, and that OCSLA and FLPMA limit Executive Branch authority to make and revoke withdrawals to an extent that had been lacking through the first half of the twentieth century. This Part also assesses the legality of the Trump Administration's withdrawal revocation efforts to date, concluding that the most prominent and controversial revocations exceeded the authority provided by FLPMA and OCSLA. The judicially recognized constraints discussed in this Part further bolster the conclusion that Congress's preference in the modern area of mineral withdrawals was to allow development of these resources only after adequate consideration of environmental values and in "close call" situations, for withdrawn lands to remain withdrawn. Part IV concludes with a summary of the limitations on Executive Branch withdrawal, modification, and revocation authority under OCSLA and FLPMA and of how the Trump Administration's missteps in this area have made the road to energy dominance quite rocky indeed.

\section{THE HISTORY OF WITHDRAWALS AND REVOCATIONS PRIOR TO OCSLA AND FLPMA}

Before Congress organized the system of offshore and onshore withdrawals and revocations in OCSLA and FLPMA, the United States had experienced nearly two hundred years of rapid expansion and economic growth, spurred in large part by the federal government's laws 


\section{Draft: Please do not cite without authors' permission}

To be published at 33 Geo. EnVtL. L. ReV., ISSUE \# 2

and policies that encouraged settlement and development of natural resources on federal lands. ${ }^{52}$

Many of these early laws were enacted pursuant to the Constitution's Property Clause, which gives Congress the power to "dispose of and make all needful rules and regulations respecting" federal property. ${ }^{53}$ Throughout the nineteenth and twentieth centuries, Congress used this power liberally to enact statutes that encouraged private development of federal lands and natural resources, and even provided for processes by which states, railroads, corporations, and individuals could obtain title to federal lands and resources, like timber, minerals, and water. ${ }^{54}$ Congress authorized development of onshore lands and natural resources in statutes that included the Preemption Act, ${ }^{55}$ the General Mining Law,${ }^{56}$ the Homestead Act,${ }^{57}$ the Desert Lands Act, ${ }^{58}$ and the Stock-Raising Homestead Act. ${ }^{59}$ The basic mechanism of each disposal-era statute was the promise of a private right in federal lands or natural resources in exchange for the effort involved in extracting or using the resource, for a modest (or sometimes nonexistent) fee, ${ }^{60}$ based on Congress's assumption that the development it hoped these give-aways would spur would be of great value to the rapidly expanding nation. ${ }^{61}$ In a similar vein, Congress also disposed of

\footnotetext{
${ }^{52}$ George C. Coggins et Al., Federal Public Land And NAtural Resources LaW 108 (7th ed. 2014).

${ }^{53}$ U.S. CONST. art. IV, $\S 3$, cl. 2.

${ }^{54}$ See, e.g. Camfield v. United States, 167 U.S. 518, 528 (1897) (discussing statutes permitting grazing and privatization of water rights on federal lands); see COGGINS ET AL., supra note 52, at 45-46, 108 (discussing land grants to individuals, states, railroads, and other corporations); see also Robert B. Keiter, Public Lands and Law Reform: Putting Theory, Policy, and Practice in Perspective, 2005 Utah L. Rev. 1127, 1131 (2005).

${ }_{55}^{55}$ General Preemption Act of 1841, 5 Stat. 453.

5630 U.S.C. $\S \S 22-47$.

5743 U.S.C. $\S \S 201-202$ (repealed by Pub. L. 94-579, Title VII, § 702, 90 Stat. 2787 (Oct. 21, 1976)).

${ }^{58} I d$. §§ 321-339 (partially repealed by Pub. L. 94-579, Title VII, § 702, 90 Stat. 2787 (Oct. 21, 1976)).

${ }^{59}$ Id. $\S \S 291-301$ (repealed by Pub. L. 94-579, Title VII, § 702, 90 Stat. 2787 (Oct. 21, 1976)).

${ }^{60}$ See COGGINS ET AL., supra note 52, at 91 (stating that the federal government disposed of land to private parties "in order to spur economic and social development of the nation"); 1 COGGINS \& GLICKSMAN, supra note 39, § 2.5 ("The main purpose of the [General] Mining Law was to promote mineral development."); Keiter, supra note 54, at 1132 ("Congress employed the Homestead Act of 1862, the Desert Lands Act of 1877, the General Mining Law of 1872 , and other such laws to attract prospective settlers and entrepreneurs to the western frontier with the enticement of virtually free land and minerals.").

${ }^{61}$ See Keiter, supra note 54, at 1132 ("Driven by the prevailing national commitment to laissez-faire capitalism, federal policy viewed private ownership and initiative as an essential element of social progress.").
} 


\section{Draft: Please do not cite without authors' permission}

To be published at 33 GEO. ENVTL. L. REV., IssuE \# 2

federal lands and mineral rights to newly admitted states to fund transportation projects and public schools, to railroad companies in an effort to facilitate the construction of transcontinental rail lines, and to fund the construction of dams and other reclamation projects that further aided western settlement and expansion. ${ }^{62}$ The chronological evolution of federal lands policy from 1800-1900 therefore provides a rough framework within which to analyze early withdrawals and revocations. In that period, the federal government was largely engaged in acquisition of lands from foreign governments and Indian tribes, and the disposition of the newly acquired lands to states, railroads, private corporations, and individuals. ${ }^{63}$ As of the turn of the twentieth century, federal lands policy began to tilt away from wholesale disposition and toward a period of disposal and retention. ${ }^{64}$ The following sections trace the use of the withdrawal and revocation mechanisms during those respective periods.

A. 1800-1900: Acquisition, Disposal, and the Pursuit of Manifest Destiny

As noted above, the period from 1800-1900 is largely characterized as one of acquisition and disposal, in which Congress and the Executive Branch encouraged expansion of the nation's physical footprint through disposal of land, timber, minerals, water, and other resources for use by states, private corporations, and individuals. ${ }^{65}$ Yet, despite the prevailing federal policy of disposition, not every land and resource management decision in the nation's early years reflected the federal government's inclination to shed federal lands and resources. Rather, Congress exercised the disposal and retention powers concurrently, even during times of rapid

\footnotetext{
${ }^{62}$ CogGins ET AL., supra note 52, at 45, 97.

${ }^{63}$ Id.; David H. Getches, Managing the Public Lands: The Authority of the Executive to Withdraw Lands, 22 NAT. RESOURCES J. 279, 281 (1982).

${ }^{64}$ Getches, supra note 63, at 283-84.

${ }^{65}$ See CoGgINS ET AL., supra note 52, at 91; 1 CoGgINS \& GLICKSMAn, supra note 39, § 2.5; Keiter, supra note 54, at 1132 .
} 


\section{Draft: Please do not cite without authors' permission}

To be published at 33 Geo. EnVtL. L. ReV., ISSUE \# 2

development. ${ }^{66}$ In the first half of the nineteenth century, Congress sought to retain some federal lands and important natural resources, usually as military reserves or Indian reservations, even as it authorized the privatization of others through the statutory mechanisms of the Preemption Act, the Homestead Acts, the railroad and state land grants, and others. ${ }^{67}$

The first congressional withdrawals, which occurred in the early 1800 s, were onshore, as Congress sought to set aside lands for Indian tribes and the military. ${ }^{68}$ The Executive Branch also made onshore withdrawals during this period, for similar reasons. International maritime laws and treaties governed offshore submerged lands, and in its landmark 1845 decision, Pollard $v$. Hagan, the Supreme Court recognized state control of the tidal lands under Mobile Bay as an incident of Alabama's sovereignty ${ }^{69}$ Tensions over offshore withdrawals would not come to a head until later, when the capability to develop offshore oil reserves arose.

Onshore, the pace at which settlers, corporations, and railroads moved westward was rapid, spurred by notions such as Manifest Destiny and the desire to prove to the world that the United States was a true player on the international stage. ${ }^{70}$ Withdrawals were necessary during

\footnotetext{
${ }^{66}$ Congress used the retention power early in the nation's history, for example, to establish reservations for Indian tribes, whose removal from what became federal lands was essential to ensuring the success of the federal expansion policies of the nineteenth century. See United States v. Celestine, 215 U.S. 278, 285 (1909).

${ }^{67}$ COGGINS ET AL., supra note 52, at 17-18. Professors Coggins and Glicksman describe an "age of disposition" running from 1787-1934 and an "age of conservation" spanning 1872 to 1964. As the dates indicate, these were "nonexclusive, overlapping historic eras." 1 COGGINS \& GLICKSMAN, supra note 39, § 2:1. They characterize the period from 1964 to the present as the "age of preservation." Id. § 2:16. See also Robert L. Glicksman \& George Cameron Coggins, Federal Recreational Land Policy: The Rise and Decline of the Land and Water Conservation Fund, 9 COLUM. L. ENVTL. L. 125, 128 (1984) ("Only gradually did a policy of federal land retention, characterized by conservation-oriented management, overcome the contrary, longstanding policy to dispose of all federal lands. The retention policy has now prevailed for over half a century."). The Trump Administration's quest for "energy dominance" has moved management of federal lands and resources markedly back toward disposition, to a greater extent than at any time since at least the first term of the Reagan Administration. For discussion of the Reagan Administration's disposition policies, see generally Coggins \& Nagel, Watt, supra note 51.

${ }^{68}$ Getches, supra note 63, at 283.

6944 U.S. (3 How.) 212, 215-16 (1845) ("A right to the shore between high and low water-mark is a sovereign [state] right.").

${ }^{70}$ See Raymond Cross, Sovereign Bargains, Indian Takings and the Preservation of Indian Country in the 21st Century, 38 PuB. LAND \& ResourCes L. REV. 15, 34 (2017) (discussing role of Manifest Destiny in federal government's "empire-building" process).
} 


\section{Draft: Please do not cite without authors' permission}

To be published at 33 GEO. ENVTL. L. REV., IssuE \# 2

this period for various reasons, but the concurrent exercise of withdrawal authority by the Executive Branch and Congress during the nineteenth century raised questions about the Executive Branch's power to reverse a withdrawal as early as the $1860 \mathrm{~s} .{ }^{71}$ For instance, on November 8, 1862, Attorney General Edward Bates, addressing the issue of whether President Abraham Lincoln had the power to return lands within Fort Armstrong in Rock Island, Illinois, to "the body of the public lands," concluded that he did not. ${ }^{72}$ Bates reasoned that the President "derived his authority to appropriate this land ... not from any power over the public land inherent in his office, but from an express grant of power from Congress." ${ }^{, 73}$ Although the President clearly had the authority, vested by statute, to withdraw lands for military facilities and authorize uses of those lands for military purposes, Bates surmised that he "had no power to take them out of the class of reserved lands, and restore them to the general body of public lands." The authority to revoke a prior withdrawal was lacking because "[i]t is certain that no such power is conferred on the President in the act under which the selection of a site for Fort Armstrong was made."75

When questions continued to arise on this matter, Bates' successors shared his view that the Executive Branch lacked inherent authority to revoke prior withdrawals of federal lands. ${ }^{76}$ In 1881, President James A. Garfield's Attorney General, Wayne MacVeagh, was asked to analyze a proposed revocation at Fort Fetterman in the Wyoming Territory. ${ }^{77}$ The precise question put to MacVeagh was whether a president may revoke a predecessor's prior reservation of lands for

\footnotetext{
${ }^{71}$ Kevin O. Leske, "Un-Shelfing” Lands Under the Outer Continental Shelf Lands Act (OCSLA): Can A Prior Executive Withdrawal Under Section 12(a) Be Trumped by A Subsequent President?, 26 N.Y.U. ENVTL. L.J. 1, 3233 (2017).

${ }^{72} I d$.

${ }^{73} \mathrm{Id}$.

${ }^{74} I d$.

${ }^{75} \mathrm{Id}$.

${ }^{76} I d$. at 33-34.

${ }^{77} I d$. at 34 .
} 


\section{Draft: Please do not cite without authors' permission}

To be published at 33 GEO. ENVTL. L. REV., ISSUE \# 2

military purposes and "'restore the lands to the public domain." ${ }^{78}$ MacVeagh concluded that he did not, because when the president withdraws land from mineral disposition, the affected land "'becomes severed from the mass of public lands and appropriated to a particular public use by authority of Congress, which alone can authorize such disposition of the public domain.",79

Complicating matters somewhat was the fact that the Executive Branch and Congress were each exercising withdrawal authority. Congress's first major withdrawal for conservation purposes was the creation of Yellowstone National Park in $1872 .{ }^{80}$ In the late nineteenth century, Congress began to codify other more permanent withdrawals, and other permanent forms of protection, for certain lands and resources, starting with onshore areas that were deemed to be of too great a value to the nation to allow them to be privately owned or developed. ${ }^{81}$ In 1891 , Congress passed the General Revision Act, which gave the Executive Branch the authority to create forest reserves. ${ }^{82}$ Shortly thereafter, Congress passed the Forest Service Organic Act, which established an agency to manage and conserve the forest reserves, and mandated that it organize the practice of timber harvesting on the newly established forest units. ${ }^{83}$ The Organic Act also delegated to the President the authority to "revoke, modify, or suspend any and all Executive orders and proclamations" issued under section 471 of the Act, "from time to time as he shall deem best for the public interests." 84

\footnotetext{
${ }^{78} I d$. (quoting Military Reservation at Fort Fetterman, 17 Op. Att'y Gen. 168 (1881)).

${ }^{79} \mathrm{Id}$. (quoting Military Reservation at Fort Fetterman, 17 Op. Att'y Gen. 168 (1881)).

${ }^{80}$ Raymond A. Peck, Jr., And Then There Were None: Evolving Federal Restraints on the Availability of Public Lands for Mineral Development, 25 RocKY MTN. MIN. L. INST.-INST. 3 (1979).

${ }^{81}$ COGGINS ET AL., supra note 52, at 108 (discussing how demographic changes and "growing recognition of the shortcomings of public land disposal policy ... contributed to the rise of a powerful national conservation movement that would significantly limit, and eventually replace, disposal policy"). The exempted lands included Indian Reservations, which became permanent homelands for hundreds of tribes after the treaty making period ended in 1871. See Hillary M. Hoffmann, Congressional Plenary Power and Indigenous Environmental Stewardship: The Limits of Environmental Federalism, 97 OR. L. REV. 353, 362-63 (2019).

${ }^{82}$ Ch. 561, 26 Stat. 1095 (1891); Getches, supra note 63, at 291.

${ }^{83} 16$ U.S.C. $\S \S 471-546$.

${ }^{84}$ Id. $\S 473$.
} 


\section{Draft: Please do not cite without authors' permission}

To be published at 33 GEO. ENVTL. L. REV., ISSUE \# 2

Generally speaking, the powers of reservation and withdrawal allowed Congress and the Executive Branch to implement temporary or permanent legal prohibitions on privatization of lands and individual resources. ${ }^{85}$ The withdrawals, which were temporary or permanent, ${ }^{86}$ removed the affected lands from the operation of the disposal and development laws, thus preventing activities such as homesteading or the acquisition of water or mineral rights in the withdrawn area. ${ }^{87}$ When withdrawn lands were also reserved, sometimes simultaneously with the withdrawal, their use was limited to affirmative purposes described in the reserving document. Often, that purpose was to conserve the named resource for a specific future use. ${ }^{88}$ Withdrawals served varied purposes. ${ }^{89}$ Congress permanently withdrew certain lands by statute to create national parks, military reserves, and Indian reservations. ${ }^{90}$ Presidents also used executive order withdrawals to create or enlarge Indian reservations, military reservations, and bird reserves. ${ }^{91}$ During the disposal period, in which federal lands and resources (onshore and offshore) were largely open for the taking, the Executive Branch used the mechanism of withdrawal to impede wholesale divestiture or complete privatization of certain federal resources, which was especially

\footnotetext{
${ }^{85}$ Robert L. Glicksman, Severability and the Realignment of the Balance of Power Over the Public Lands: The Federal Land Policy and Management Act of 1976 After the Legislative Veto Decisions, 36 Hastings L.J. 1, 9-10 (1984) [hereinafter Glicksman, Severability]; Midwest Oil, 236 U.S. at 467 (noting that President Taft's 1909 proclamation restricting the disposition of petroleum deposits on federal lands in California and Wyoming was temporary).

${ }^{86}$ Glicksman, Severability, supra note 85 , at 9-10.

${ }^{87} \mathrm{Id}$.

${ }^{88}$ Midwest Oil, 236 U.S. at 470-71; see also Getches, supra note 63, at 279. In Getches' view: Withdrawal remains an important device in federal land use planning and management. Significant fragile wildlife habitat may need protection from mining pending consideration of legislation to designate it as a park or wildlife refuge. Lands rich in petroleum or oil shale may be removed from operation by statutes that would allow private uses and development because they can be developed most efficiently under a coordinated national program. Wild areas may be protected from commercial uses so that they may remain in their pristine state. Today, public land managers may have several ways to accomplish their desired results. Yet one of the most effective means is withdrawal.

Id.

${ }^{89}$ Glicksman, Severability, supra note 85 , at 9-10.

${ }^{90}$ Midwest Oil, 236 U.S. $469-70$ (citing Grisar v. McDowell, 73 U.S. 363 (1867); Wolsey v. Chapman, 101 U.S. 769 (1879); Donnelly v. United States, 228 U.S. 255 (1913)).

${ }^{91}$ Midwest Oil, 236 U.S. at 470.
} 


\section{Draft: Please do not cite without authors' permission}

To be published at 33 GEO. ENVTL. L. REV., ISSUE \# 2

effective because the Executive Branch could make a withdrawal much more expediently than Congress. $^{92}$

As the twentieth century drew near, Congress and the Executive Branch accelerated the pace of withdrawals. ${ }^{93}$ President Theodore Roosevelt has been lauded as the first champion of the Executive withdrawal effort, starting with his onshore withdrawals creating forest reserves in 1891. ${ }^{94}$ As discussed below, other Presidents followed suit, withdrawing onshore lands for a variety of purposes, including as wildlife refuges, sources of clean water for consumptive use, national monuments, and as national oil reserves to support the U.S. economy's increasing dependence on oil. ${ }^{95}$ Meanwhile, Congress continued its own practice of making withdrawals, and began delegating authority to the Executive Branch to make withdrawals in specific circumstances. ${ }^{96}$

B. 1900-1950: Transitioning into Retention and Conservation, and Growing Questions About Withdrawal and Revocation Authority.

Onshore withdrawals continued during the period from 1900-1950s, but Congress asserted its Property Clause authority to organize withdrawals (and revocations, to a lesser degree) more during this time than before. ${ }^{97}$ Conflict over governance of mineral development

\footnotetext{
${ }^{92} I d$. (noting that many of these early Executive withdrawals were made in the absence of statutory authorization).

${ }^{93}$ Nat'l Mining Assn' v. Zinke, 877 F.3d 845, 854 (9th Cir. 2018).

${ }^{94}$ See Mark Squillace, Rethinking Public Land Use Planning, 43 HARV. EnVTL. L. ReV. 415, 420 (2019).

${ }^{95}$ Mark Squillace, The Monumental Legacy of the Antiquities Act of 1906, 37 GA. L. REV. 473, 493 (2003) [hereinafter Squillace, Legacy] (noting that the six Presidents who followed Roosevelt established national monuments "with surprising vigor"); COGGINS ET AL., supra note 52, at 25-28. Roosevelt also created a federal agency, the U.S. Forest Service, to manage the forest reserves in particular, and soon after its creation, the Forest Service expanded the reserve system by acquiring private forests and other lands pursuant to various acts of Congress, such as the Weeks Act of 1911, 16 U.S.C. $\S \S 515-521$ (2018). See CoGGINS ET AL., supra, at 25.

${ }^{96}$ John C. Ruple, The Trump Administration and Lessons Not Learned from Prior National Monument Modifications, 43 HARV. ENVTL. L. REV. 1, 27 (2019) (quoting Act of July 5, 1884, 23 Stat. 103, 103 (1884) (in which Congress authorized President to determine whether lands within military reservations were "useless for military purposes" and nominate such lands for "disposition.”). See also Act of Oct. 2, 1888, 25 Stat. 505, 527 (1888) (repealed 1976), in which Congress recognized the President's power to reserve lands from settlement and said that "the President may at any time in his discretion by proclamation open any portion or all of the lands reserved by this provision to settlement under the homestead laws.

${ }^{97} \mathrm{Id}$. at $27-28$.
} 


\section{Draft: Please do not cite without authors' permission}

To be published at 33 GEO. ENVTL. L. REV., IssuE \# 2

also brewed offshore, as coastal states began authorizing offshore oil and gas operations, passing statutes that allowed prospectors to access the oil reserves of the inner continental shelf, despite the federal government's claims of authority looming in the background.$^{98}$ State control reaching three miles from shore was uncontroversial and unchallenged, though, even by the federal government, which recognized state claims to on these lands as nearly absolute. ${ }^{99}$ Despite the concession that states owned the nearshore submerged lands, momentum for transition to a new regime of increased federal control over the submerged lands farther from shore began building as early as 1937 , when Interior Secretary Harold Ickes asked a member of the Senate to introduce legislation declaring the marginal seabed ${ }^{100}$ to be within the national domain. Coastal states vigorously opposed the measure, which ended quickly in defeat. ${ }^{101}$ But Ickes persisted, and eventually found a more receptive audience in the Executive Branch, convincing President Truman to file a lawsuit that ultimately induced Congress to pass OCSLA. ${ }^{102}$

Although Congress delegated authority to the Executive Branch to make, modify, and revoke withdrawals, for various reasons, through the early decades of the twentieth century, Executive Branch withdrawals were sometimes made in the absence of an express delegation of authority from Congress, under the general justification that the Executive Branch possessed inherent power over federal public resources and federal territory, along with a direct responsibility to the American public to protect those resources from outright depletion. ${ }^{103}$ Presidents also cited the compelling public interest in halting resource disposition in the absence

\footnotetext{
${ }^{98}$ See Daniel S. Miller, Offshore Federalism: Evolving Federal-State Relations in Offshore Oil and Gas Development, 11 ECOLOGY L.Q. 401, 405 (1984) ("Until 1937, state ownership of adjacent tide and submerged lands, to a distance of three miles from shore, was virtually unquestioned.").

${ }^{99} I d$. at 406.

100 "The marginal sea is defined as the three-mile belt of ocean whose inner boundary is the mean high tide line." Id. at $402 \mathrm{n} .1$ (citing 43 U.S.C. $\S 1301$ (a)(2)).

${ }^{101} \mathrm{Id}$. at 407.

${ }^{102} I d$. For a discussion of the enactment of OCSLA, see infra Part III.

${ }^{103} I d$. at $470-71$.
} 


\section{Draft: Please do not cite without authors' permission}

To be published at 33 GEO. ENVTL. L. REV., ISSUE \# 2

of timely congressional action. In that circumstance, as mentioned above, ${ }^{104}$ the Executive was sometimes the only bulwark against potentially irreversible losses of federal lands and resources. $^{105}$

The Executive Branch's sometimes prolific use of withdrawal authority that was not delegated by statute spurred increasing questions about its scope, and whether the Executive Branch also possessed similar nonstatutory authority to revoke prior withdrawals. There was no real judicial scrutiny of these questions until the landmark Supreme Court opinion in United States v. Midwest Oil. ${ }^{106}$ The circumstances leading to that case began when Congress passed a statute in 1897 opening "all public lands containing petroleum or other mineral oils" to exploration and development by private parties. ${ }^{107}$ In the ensuing years, there was such an intense oil rush on federal lands in California that the U.S. Geological Survey (USGS) warned that "at the rate at which oil lands in California were being patented ${ }^{108}$ by private parties, it would be impossible for the people of the United States to continue ownership of oil lands for more than a few months. After that the government will be obliged to repurchase the very oil that it has practically given away [in the 1897 statute]." 109 The USGS advised "immediate" action to prevent this possibility. ${ }^{110}$

Heeding the warning, President Taft issued a presidential proclamation withdrawing oil reserves in California and Wyoming, which went into effect immediately. ${ }^{111}$ The proclamation

\footnotetext{
${ }^{104}$ See supra notes $91-92$ and accompanying text.

${ }^{105} \mathrm{Id}$. at 471 .

${ }^{106}$ See Glicksman, Severability, supra note 85, at 13.

${ }^{107}$ Midwest Oil, 236 U.S. at 466.

108 Patenting is a process by which the federal government transfers title to another entity, such as a company that has explored for and discovered valuable mineral deposits on federal land. See Chevron Mining Inc. v. United States, 863 F.3d 1261, 1272 (10 ${ }^{\text {th }}$ Cir. 2017) ("Issuance of a patent transfers title in the underlying public land from the United States to the patent holder.").

${ }^{109} \mathrm{Id}$. at 466-67 (internal quotations omitted).

${ }^{110} I d$. at 467.

${ }^{111} I d$. (citing Presidential Proclamation, Temporary Petroleum Withdrawal No. 5 (Sept. 27, 1905)).
} 


\section{Draft: Please do not cite without authors' permission}

To be published at 33 GEO. ENVTL. L. REV., IssuE \# 2

stated that it was issued "[i]n aid of proposed legislation" and temporarily withdrew more than three million acres of land in California and Wyoming "from all forms of location, settlement, selection, filing, entry, or disposal under the mineral or nonmineral public-land laws." ${ }^{112}$ Six months later, the predecessors in interest to Midwest Oil Company entered upon withdrawn lands in Wyoming and drilled an exploratory well, rights to which were later acquired by Midwest Oil. ${ }^{113}$ When the federal government filed suit against the company in federal district court in Wyoming, Midwest Oil's defense included a challenge to the validity of the Proclamation. The company's argument was that the President lacked authority to make an emergency withdrawal of the lands containing Midwest Oil's wells. ${ }^{114}$

Despite acknowledging the lack of an explicit statutory basis for Taft's emergency withdrawal, the Court found that the national public interest in retaining the oil reserves was sufficient to validate the Proclamation. ${ }^{115}$ Specifically, the Court reasoned that

when it appeared that the public interest would be served by withdrawing or reserving parts of the public domain, nothing was more natural than to retain what the government already owned. And in making such orders, which were thus useful to the public, no private interest was injured. For, prior to the initiation of some right given by law, the citizen had no enforceable interest in the public statute, and no private right in land which was the property of the people. ${ }^{116}$

The Court found it particularly compelling that Congress had been aware of this practice of nonstatutory Executive withdrawals for approximately eighty years, but had done nothing to disturb or prevent it. ${ }^{117}$ As the Supreme Court noted, "[t]hese [executive] orders were known to Congress, as principal, and in not a single instance was the act of the [President] disapproved.

${ }^{112} I d$. (quoting Presidential Proclamation, Temporary Petroleum Withdrawal No. 5 (Sept. 27, 1905)).

${ }^{113} I d$.

${ }^{114} \mathrm{Id}$. at 470 .

${ }^{115} \mathrm{Id}$. at $472-73$.

${ }^{116} \mathrm{Id}$. at 471.

${ }^{117}$ Midwest Oil, 236 U.S. at 469, 472-73 (also noting the support of the Secretary of the Land Department for the Executive withdrawals of the late nineteenth century). 


\section{Draft: Please do not cite without authors' permission}

To be published at 33 GEO. ENVTL. L. REV., ISSUE \# 2

[Congress's] acquiescence all the more readily operated as an implied grant of power in view of the fact that its exercise was not only useful to the public, but did not interfere with any vested right of the citizen." ${ }^{118}$ Accordingly, the Court held that it was not unlawful for the President to make the withdrawals in question. ${ }^{119}$

The legislation that Taft's withdrawals aided was the Pickett Act, passed in 1910. That statute clarified the scope of the executive's withdrawal power. ${ }^{120}$ The Pickett Act authorized the President, "at any time, and within his discretion, to "temporarily withdraw from settlement, location, sale, or entry any of the public lands ... and reserve the same for water-power sites, irrigation, classification of lands, or other public purposes. ..." ${ }^{121}$ The Act's withdrawal authority did not apply to lands bearing minerals other than coal, oil, gas and phosphates, though, which limited its scope significantly. ${ }^{122}$ Congress did clarify that a presidential Pickett Act withdrawal remained "in effect until revoked by him or by an Act of Congress," 123 and required the Secretary of Interior to report all withdrawals to Congress. ${ }^{124}$ The statute thus conferred

\footnotetext{
${ }^{118} \mathrm{Id}$. at 475; see also id. at 472-73 ("Both officers, lawmakers, and citizens naturally adjust themselves to any longcontinued action of the Executive Department, on the presumption that unauthorized acts would not have been allowed to be so often repeated as to crystallize into a regular practice. That presumption is . . but the basis of a wise and quieting rule that, in determining the meaning of a statute or the existence of a power, weight shall be given to the usage itself. ..."). ${ }^{119} \mathrm{Id}$. at 483 .

${ }^{120}$ Ch. 421, 36 Stat. 847 (1910) (codified at 43 U.S.C. §§ 141-142) (repealed by Pub. L. No. 94-579, § 704(a), 90 Stat. 2743, 2792 (1976)); John F. Shepherd \& Shawn T. Welch, Public Land Withdrawals: The Age-Old Struggle over Federal Land Management Policy Continues, 61 RocKY MTN. Mineral L. Found.-Inst. 9-1 (2015) (citing Charles F. Wheatley, Study of Withdrawals and Reservations of Public Domain Lands (PLLRC 1969)). The Court in Midwest Oil noted that the Pickett Act "operated to restrict the greater [Executive] power already possessed." Midwest Oil, 236 U.S. at 482.

Several years earlier, Congress had adopted the Antiquities Act of 1906, which authorizes the President to reserve as national monuments "historic landmarks, historic and prehistoric structures, and other objects of historic or scientific interest that are situated on land owned or controlled by the Federal Government," provided the reserved parcels are "confined to the smallest area compatible with the proper care and management of the objects to be protected." 54 U.S.C. $\S 320301(a)-(b)$.

${ }^{121}$ Ch. 421, 36 Stat. 847 (1910) (codified at 43 U.S.C. § 141) (repealed by Pub. L. No. 94-579, § 704(a), 90 Stat. 2743, $2792(1976))$.

${ }^{122} I d$.

${ }^{123} I d . \S 1$.

${ }^{124} I d$. $\S 3$.
} 


\section{Draft: Please do not cite without authors' permission}

To be published at 33 GEO. ENVTL. L. REV., ISSUE \# 2

limited authority to the Executive to temporarily withdraw lands bearing coal, oil, gas, or phosphates, and authority to revoke such withdrawals, but it reserved to Congress the power to make more permanent decisions about the status of a given tract. ${ }^{125}$

The Midwest Oil opinion and the Pickett Act are somewhat helpful in defining the scope of early to mid-twentieth century Executive withdrawal authority. In Midwest Oil, the Court held that the President had made multitudes of nonstatutory withdrawals, including the withdrawal at issue in the case, and that since Congress had not rebuked these Presidential acts, or curbed the Executive's authority in any way through legislation, they were lawful. ${ }^{126}$ The Court's reasoning indicated that the President was able to preserve from sale or disposition the lands of the American people, as "any other owner of property could under similar conditions." 127 Simultaneously, the Court recognized that Congress had legislative power over the federal lands, and that it bore a burden of sorts to assert this power when the acts of the Executive became untenable or controverted Congress's will. ${ }^{128}$ At least one commentator has also observed that although many withdrawals made by the Executive lacked direct statutory authorization, "in most cases they were compatible with an existing policy reflected in statute." 129 Yet, the opinion left almost as many questions unanswered, such as whether the

\footnotetext{
${ }^{125} \mathrm{Id}$. Presidents nevertheless exercised their authority to make withdrawals under the Pickett Act "vigorously" until Congress repealed the Act upon the adoption of FLPMA in 1976. See 2 COGGINS \& GLICKSMAN, supra note 39, § 14:8.

${ }^{126}$ Midwest Oil, 236 U.S. at 471.

${ }^{127}$ Id. at 474. The Court expounded on this owner/agent in charge theory thus: These rules or laws for the disposal of public land are necessarily general in their nature. Emergencies may occur, or conditions may so change as to require that the agent in charge should, in the public interest, withhold the land from sale; and while no such express authority has been granted, there is nothing in the nature of the power exercised which prevents Congress from granting it by implication just as could be done by any other owner of property under similar conditions. The power of the Executive, as agent in charge, to retain that property from 


\section{Draft: Please do not cite without authors' permission}

To be published at 33 GEO. ENVTL. L. REV., ISSUE \# 2

President could revoke by executive order a congressional withdrawal, ${ }^{130}$ and whether there exists inherent presidential revocation authority or revocation authority that is implied within or accompanies explicit statutory withdrawal authority.

The Pickett Act answered some of these remaining questions, by explicitly authorizing withdrawal revocations, but withdrawals were temporary to begin with anyway, and the authority to revoke may have been limited to a President's own withdrawals. Thus, the Pickett Act was never intended as a tool for Presidents to permanently withdraw lands and resources from development or exploitation. ${ }^{131}$ Interestingly, though, some Pickett Act withdrawals effectively became permanent because they went unrevoked by a subsequent President or by Congress. ${ }^{132}$ Thus, executive withdrawals under the Pickett Act often ended up as "interminable" temporary withdrawals, even though this was never intended in the Act. ${ }^{133}$ Moreover, despite the Pickett Act's attempted clarification of the scope of Executive Branch authority to make and revoke withdrawals, attempts to invoke nonstatutory withdrawal authority continued well into the twentieth century. ${ }^{134}$

Franklin D. Roosevelt's election ushered in a particularly large wave of withdrawals, mostly pursuant to statutory delegations like the Antiquities Act. ${ }^{135}$ FDR used his Antiquities Act withdrawal authority to create eleven new national monuments, including Joshua Tree National Monument, Jackson Hole National Monument, and Capitol Reef National

\footnotetext{
${ }^{130}$ Midwest Oil, 236 U.S. at 469.

131 Getches, supra note 63, at 292-93.

132 Shepherd \& Welch, supra note 120, at 9-8; 2 CoGgINS \& GLICKSMAN, supra note 39, § 14:10 n. 4.

${ }^{133}$ Id. Pickett Act withdrawals were nevertheless sometimes controversial. See United States v. Mammoth Oil Co., 5 F.2d 330 (D. Wyo. 1925), rev'd, 14 F.2d 705 (8th Cir. 1926) (reviewing 1915 Taft withdrawal of oil reserves located near Teapot Dome in Wyoming, to serve as permanent naval oil reserve, and subsequent secret executive order transferring authority over reserves to the Department of Interior, resulting in congressional investigation and forced cancellation of leases).

${ }^{134}$ Portland Gen. Elec. Co. v. Kleppe, 441 F. Supp. 859, 861 (D. Wyo. 1977) (declaring that the Pickett Act did not "destroy" the President's authority to make nonstatutory withdrawals).

135 Squillace, Legacy, supra note 95, at 481-82, 494.
} 


\section{Draft: Please do not cite without authors' permission}

To be published at 33 GEO. ENVTL. L. REV., ISSUE \# 2

Monument. ${ }^{136}$ Many of these designations, and particularly the Jackson Hole Monument, stirred controversy in the affected areas and in Congress, where some members felt that Roosevelt's use of the Antiquities Act authority exceeded the bounds of the statutory delegation. ${ }^{137}$ In fact, Congress responded to FDR's designation of the Jackson Hole National Monument with an amendment to the Antiquities Act, eliminating the President's unilateral authority to create national monuments in the state of Wyoming. ${ }^{138}$ Yet, Congress also ultimately affirmed some of FDR's withdrawals, enveloping the lands within Jackson Hole National Monument into Grand Teton National Park in 1950 and, much later, creating Joshua Tree National Park from the FDR monument of the same name in $1994 .{ }^{139}$

The mix of congressional and Executive Branch withdrawals and withdrawal revocations that had occurred by the middle of the twentieth century resulted in a management regime that the Supreme Court later labeled as "chaotic." ${ }^{140}$ Part of the reason for this was that by the late 1950s, various statutes authorized Executive Branch withdrawals to prohibit mineral development and other uses, and provided limited Executive Branch authority to revoke prior withdrawals. ${ }^{141}$ Yet, the Midwest Oil decision did not definitively resolve the question of whether the Executive Branch retained inherent withdrawal authority, and did not touch the question of inherent revocation authority. At the same time, Congress was still withdrawing tracts of federal lands and reserving them for public purposes, which resulted in restrictions and

\footnotetext{
${ }^{136}$ Id. FDR's creation of Jackson Hole National Monument (which was eventually converted by Congress into Grand Teton National Park) was so controversial in Wyoming, and elsewhere in the west, that it spurred Congress to amend the Antiquities Act to prohibit the President from withdrawing lands as national monuments after 1950. Id. at 498 (citing 16 U.S.C. $§ 431$ a, repealed by Pub. L. 113-287, § 7, Dec. 19, 2014, 128 Stat. 3272 and recodified at 54 U.S.C. § 320301(d)).

${ }^{137}$ Squillace, Legacy, supra note 95, at 498, n. 136.

138 Id.

$139 \mathrm{Id}$

${ }^{140}$ Lujan v. Nat'1 Wildlife Fed'n, 497 U.S. 871, 876 (1990).

${ }^{141} I d$.
} 


\section{Draft: Please do not cite without authors' permission}

To be published at 33 GEO. ENVTL. L. REV., IssuE \# 2

authorizations that sometimes overlapped, making it difficult to ascertain the precise status of a given area of federal lands at any one point in time. ${ }^{142}$ Complicating matters further, inadequate records of withdrawals made it impossible to determine the scope of acceptable uses of individual tracts. ${ }^{143}$ Recognizing the uncertainty that this patchwork of statutes and Executive Branch actions created, Congress decided that it was time to clarify and rationalize the system, starting with the offshore submerged lands.

\section{CONGRessional ATtempts to ORganize the ChaOs: THE Legislative History of the Outer Continental Shelf Lands ACt and the Federal Land Policy AND MANAGEMENT ACT}

Although Congress enacted OCSLA and FLPMA more than two decades apart, they reflect a common goal of clarifying the permissible uses of particular tracts of federal lands and resources and specifying the extent and nature of Executive Branch control over such determinations. In particular, the two laws clarified the scope of the Executive Branch's authority to make withdrawals on 1.75 billion acres of submerged offshore lands (OCSLA) and 700 million acres of onshore lands (FLPMA). ${ }^{144}$ That authority and its subsequent implementation determined which tracts of federal lands were available for, or off limits to, mineral development. Presidential and agency exercise of (and limits upon) delegated statutory withdrawal authority determined the range of available and prohibited uses of the affected federal lands, making the withdrawal process a critical determinant of the nature of federal land management. This Part traces the history leading to the adoption of each statute, which informed Congress's decisions about the scope of the final enactments.

\footnotetext{
${ }^{142} I d$. (noting that by 1970, "virtually all" of the public domain had been withdrawn or classified for retention). ${ }^{143} \mathrm{Id}$.

${ }^{144}$ G. Kevin Jones, Understanding the Debate over Congressionally Imposed Moratoria on Outer Continental Shelf Oil and Gas Leasing, 9 TEMP. ENVTL. L. \& TECH. J. 117, 122 (1990); Burt, supra note 44, at 10.
} 


\section{Draft: Please do not cite without authors' permission}

To be published at 33 GEO. ENVTL. L. REV., ISSUE \# 2

\section{A. Offshore Public Mineral Development and OCSLA}

\section{The Origins of the Outer Continental Shelf Lands Act}

Before OCSLA's passage, controversies had been brewing for decades over management of offshore oil reserves in the Pacific Ocean off the coast of California and in the Gulf of Mexico near Louisiana and Texas. In the absence of governing legislation, the federal courts were tasked with resolving these disputes on a case by case basis. ${ }^{145}$ California's conflicts began in the late nineteenth century, when an offshore oil boom was triggered by a wildcatter's exploratory wells on the beach in Santa Barbara. ${ }^{146}$ After the wells yielded "encouraging results," others began cropping upon on "constructed piers..., leading to the realization that the [famous] Summerland oilfield extended offshore." ${ }^{147}$ Once the technology advanced to the point that rigs could "float" over wells in deeper waters, around 1930, offshore drilling in the Santa Barbara Channel began. ${ }^{148}$ During this early boom, California claimed ownership of submerged lands extending out three miles from the shoreline pursuant to its state constitution, and the state passed several statutes authorizing oil leasing off the coast. ${ }^{149}$

The federal government's interest in asserting authority over the submerged lands of the continental shelf increased around this time, which was during the tenure of Secretary of Interior

\footnotetext{
145 David W. Robertson, The Outer Continental Shelf Lands Act's Provisions on Jurisdiction, Remedies, and Choice of Law: Correcting the Fifth Circuit's Mistakes, 38 J. MAR. L. \& COM. 487, 493 (2007).

146 Amer. Oil \& Gas Hist. Soc'y, “Offshore Petroleum History” (Jan. 21, 2019), https://aoghs.org/offshorehistory/offshore-oil-history/ [hereinafter Offshore Petroleum History]; see also Payton A. Wells, Choose Your Laws Carefully: Executive Authority to Unilaterally Withdraw the United States Outer Continental Shelf from Leasing Disposition, 67 DUKE L.J. 863, 906 n. 37 (2018).

147 Offshore Petroleum History, supra note 146; see also Kristofer Thompson, Ownership Not Required: The Expansion of Section 167(h) in CGG Americas, Inc. v. Commissioner, 54 SAN DIEGo L. REV. 177, 178 \& n.1 (2017) ${ }^{148}$ Offshore Petroleum History, supra note 146.

149 United States v. California, 332 U.S. 19, 29 (1947), supplemented sub nom. United States v. California, 332 U.S. 804 (1947) (citing CAL. CoNST.1849, art. XII, § 1); Robertson, supra note 145, at 494 (noting that a California statute passed in 1921 "authoriz[ed] the granting of permits to California residents to prospect for oil and gas on blocks of land off its coast under the ocean. Subsequently, California executed numerous mineral leases authorizing oil and gas exploration and production in its coastal waters out to the three-mile limit."); Thomas Curwen, $A$ Historic Oil Platform off Santa Barbara Turns Into a Rusty Ghost Ship, L.A. TIMES, Mar. 14, 2019, https://www.latimes.com/projects/la-me-platform-holly/.
} 


\section{Draft: Please do not cite without authors' permission}

To be published at 33 GEO. ENVTL. L. REV., ISSUE \# 2

Harold Ickes. ${ }^{150}$ As noted above, ${ }^{151}$ Ickes's first attempt to convince Congress to establish federal control of the coastal waters and submerged lands, by lobbying for a statute to declare the marginal seabed (the lands within the three-mile offshore band) as the property of the federal government, did not succeed. He was more successful in his entreaties to the Executive Branch, however, persuading President Truman to take up the mantle of federal sovereignty over offshore submerged lands in 1945. ${ }^{152}$ Truman urged his Attorney General to file suit against California, which he did, seeking a declaratory judgment that the federal government owned the marginal seabed and an injunction halting the authorization of further development of offshore oil reserves by the state. ${ }^{153}$ Truman simultaneously issued a Presidential Proclamation stating that it was "the view of the Government of the United States that [its] exercise of jurisdiction over the natural resources of the subsoil and sea bed of the continental shelf by the contiguous nation is reasonable and just." 154 Therefore, Truman proclaimed, "the Government of the United States regards the natural resources of the subsoil and sea bed of the continental shelf beneath the high seas but contiguous to the coasts of the United States as appertaining to the United States, subject to its jurisdiction and control." ${ }^{155}$

\footnotetext{
${ }^{150}$ Miller, supra note 98 , at 407.

${ }^{151}$ See supra notes 100-102 and accompanying text.

${ }^{152}$ Miller, supra note 98 , at 407.

${ }^{153}$ Id. (citing Complaint for the United States in United States v. California, 332 U.S. 19 (1947)).

${ }^{154}$ Presidential Proclamation 2667, 10 Fed. Reg. 12303 (Oct. 2, 1945). The Proclamation also noted that federal control was necessary for several additional reasons, namely that: the effectiveness of measures to utilize or conserve these resources would be contingent upon cooperation and protection from the shore, since the continental shelf may be regarded as an extension of the land-mass of the coastal nation and thus naturally appurtenant to it, since these resources frequently form a seaward extension of a pool or deposit lying within the territory, and since self-protection compels the coastal nation to keep close watch over activities off its shores which are of the nature necessary for utilization of these resources.

Id.

${ }^{155} I d$.
} 


\section{Draft: Please do not cite without authors' permission}

To be published at 33 GEO. ENVTL. L. REV., IssuE \# 2

When the federal government challenged the numerous leases California had issued in the near-shore and offshore waters of the Pacific, the Supreme Court ruled that it, and not the states, possessed valid title to the submerged lands within three miles of the ordinary low water mark. ${ }^{156}$ The Court reasoned that federal "protection and control of [the three mile offshore belt] has ben [sic] and is a function of national external sovereignty." ${ }^{157}$ The Court also emphasized that the "[ $[$ ]he three-mile rule is but a recognition of the necessity that a government next to the sea must be able to protect itself from dangers incident to its location." ${ }^{158}$ Moreover, in the Court's view, the national government "must have powers of dominion and regulation in the interest of its revenues, its health, and the security of its people from [wars] waged on or too near its coasts." 159

Shortly after California began leasing submerged lands for oil exploration, interest in developing the offshore oil reserves of the Gulf of Mexico emerged. ${ }^{160}$ In 1911, Gulf Refining Company, which had used piers to support offshore drilling operations, abandoned them in favor of a new technology involving "a fleet of tugboats, barges, and floating pile drivers." ${ }^{161}$ When this potentially far-reaching approach paid off in exponential increases in production, Gulf began extensive drilling operations on the bed of Caddo Lake in Louisiana. ${ }^{162}$ Three decades later, two companies built a freestanding drilling platform in the Gulf of Mexico in fourteen feet of water

\footnotetext{
${ }^{156}$ United States v. California, 332 U.S. 19, 22-23 (1947), opinion supplemented, 332 U.S. 804 (1947).

157 Id. at 34 .

${ }^{158} I d$. at 35 .

${ }^{159} \mathrm{Id}$.

${ }^{160}$ See Robertson, supra note 145, at 494.

161 Offshore Petroleum History, supra note 146.

${ }^{162} \mathrm{Id}$. (noting that because these Caddo Lake wells lacked a pier connection to shore, they have "frequently been called America's first true offshore drilling").
} 


\section{Draft: Please do not cite without authors' permission}

To be published at 33 GEO. ENVTL. L. REV., IssuE \# 2

about a mile off the coast of Creole, Louisiana, ${ }^{163}$ and by the end of 1949 , the industry had established forty-four individual wells in eleven oil and natural gas fields in the Gulf. ${ }^{164}$

Spurred by the extensive and valuable offshore reserves in the Gulf Coast region, Louisiana and Texas both laid claim to all submerged lands within twenty-seven miles of the shoreline. In 1947, Texas passed a statute asserting jurisdiction from the mean low tideline to the edge of the continental shelf, about two hundred miles offshore. ${ }^{165}$ Meanwhile, President Truman's 1945 proclamation had declared federal jurisdiction over the submerged lands of the entire continental shelf, including the areas claimed by Texas and Louisiana. ${ }^{166}$ When the states continued to issue oil leases in the Gulf, despite the President's proclamation, the federal government filed separate original actions against Texas and Louisiana in the Supreme Court, seeking rulings similar to the one the Court had provided in the California suit. ${ }^{167}$ The Louisiana complaint challenged oil leases to private interests, issued pursuant to state statutes, which had drilled wells and paid bonuses, rent, and royalties to the state, without recognizing the federal government's property rights. ${ }^{168}$ Consistent with its earlier ruling in United States v. California, the Supreme Court held in these twin cases that the states' assertions of ownership and jurisdiction were unfounded, and that the United States had sole dominion over the ocean within the marginal belt and beyond, specifically including any oil reserves in that area. ${ }^{169}$

The Court's decisions in the California, Louisiana, and Texas cases antagonized many states with offshore reserves. The three losing states in particular began lobbying for a federal

\footnotetext{
${ }^{163} \mathrm{Id}$.

${ }^{164} \mathrm{Id}$.

${ }^{165}$ United States v. Texas, 339 U.S. 707, 720 (1950) (citing Act of May 23, 1947, L. Texas, 50th Leg., p. 451, VERNON's ANN. CIV. ST. art. 5415a).

166 Presidential Proclamation 2667, supra note 154.

${ }^{167}$ United States v. Louisiana, 339 U.S. 699 (1950); United States v. Texas, 339 U.S. 707 (1950).

${ }^{168} \mathrm{Id}$. at 701 .

${ }^{169} I d$. at $705-06$.
} 


\section{Draft: Please do not cite without authors' permission}

To be published at 33 GEO. ENVTL. L. REV., IssuE \# 2

quitclaim of ownership to the states. ${ }^{170}$ To quell the controversy, Congress interceded by enacting the Submerged Lands Act in 1953, whose goal was to define jurisdiction and ownership of all offshore submerged lands. ${ }^{171}$ The Act ceded the seabed and mineral resources within three miles of the shoreline to the coastal states, ${ }^{172}$ a compromise that partially appeased the states that had chafed at the Supreme Court's earlier decisions. ${ }^{173}$ The Act also gave Texas and Florida additional submerged lands and mineral resources, extending out to within nine miles of the states' coastlines. ${ }^{174}$ Congress clarified that the Act did not affect federal rights in "the natural resources of the subsoil and seabed of the continental shelf lying seaward and outside of the area of lands beneath navigable waters," so that title to those waters, lands, and resources remained with the federal government. ${ }^{175}$ Congress did not delineate the extent of its own claim of ownership for a few more months, when it enacted OCSLA.

\section{OCLSA'S Limited Delegation of Presidential Withdrawal Authority}

Congress passed OCSLA to clarify the nature and scope of federal authority over the submerged lands of the outer continental shelf. ${ }^{176}$ At the outset, OCSLA declares that the "subsoil and seabed" of the shelf "appertain to the United States and are subject to its jurisdiction, control, and power." ${ }^{177}$ Yet, because development of these resources would have

\footnotetext{
${ }^{170}$ See Warren M. Christopher, The Outer Continental Shelf Lands Act: Key to A New Frontier, 6 STAN. L. REv. 23, 41 (1953) (describing legislative history of Submerged Lands Act and OCSLA, and noting that "the advocacy of these representatives of the Gulf coastal states was skillful and flexible").

17143 U.S.C. $\$ \S 1301-1315$.

${ }^{172} I d . \S \S 1311-1312$.

${ }^{173}$ Christopher, supra note 170 , at 41

17443 U.S.C. $\S \S 1302(2), 1312$. Texas received a marine boundary of three leagues from shore by virtue of an historical claim recognized upon its admission as a state in 1845. The Act recognized Florida's marine boundary extending three leagues into the Gulf because of Article I of Florida's Constitution of 1868, approved by Congress upon readmission during Reconstruction. United States v. Louisiana, Texas, Mississippi, Alabama, \& Florida, 363 U.S. 1, 84 (1960).

17543 U.S.C. $\S 1302$.

${ }^{176} I d . \S 1332$.

${ }^{177} I d . \S 1332(1)$.
} 


\section{Draft: Please do not cite without authors' permission}

To be published at 33 GEO. ENVTL. L. REV., ISSUE \# 2

"significant impacts on coastal and non-coastal areas of the coastal states," the statute gives states the opportunity to participate in federal decision-making with respect to development of offshore mineral and other resources. ${ }^{178}$ The primary goals of the original statute were quite straightforward, though — to establish federal jurisdiction and authority over the outer continental shelf, and authorize the development of mineral resources in the newly established federal waters.

The geographic area subject to OCSLA is the band of submerged lands starting beyond the territorial waters of the United States (generally speaking, three miles out from the coastline) and extending roughly two hundred miles seaward, to the edge of the exclusive economic zone (EEZ) of the United States. ${ }^{179}$ One of the primary goals of the statute was to clarify the precise area under federal jurisdiction, which would confer regulatory power over offshore oil and gas development. ${ }^{180}$ OCSLA also created a leasing program for the mineral resources within this area, as well as allocations for establishing rights of way for pipelines and other oil and gas infrastructure. ${ }^{181}$ Congress appeared to "borrow heavily" from onshore statutes regulating mineral development in OCSLA, "suggesting strongly that Congress viewed the Outer Continental Shelf as a form of federal public lands, at least so far as developing these resources was concerned." 182

In the 1978 amendments to the original statute, Congress expanded the original policy statement significantly, clarifying that "the outer Continental Shelf is a vital national resource

\footnotetext{
${ }^{178}$ Id. $\S 1332(4)$.

${ }^{179}$ Leske, supra note 71 , at 3.

${ }^{180}$ H.R. REP. NO. 95-1474, 79, 1978 U.S.C.C.A.N. 1674, 1678 (noting that original purpose section was solely "jurisdictional").

${ }^{181} \mathrm{Id}$. at 95-1474, 86, 1978 U.S.C.C.A.N. 1674, 1685 (noting that original leasing provisions authorized leasing and also pipeline and infrastructure rights of way).

182 See Robin Kundis Craig, Treating Offshore Submerged Lands as Public Lands: A Historical Perspective, 34 PuB. LAND \& RESOURCES L. REV. 51, 78 (2013).
} 


\section{Draft: Please do not cite without authors' permission}

To be published at 33 GEO. ENVTL. L. REV., IssuE \# 2

reserve held by the Federal Government for the public, which should be made available for expeditious and orderly development, subject to environmental safeguards, in a manner which is consistent with the maintenance of competition and other national needs." ${ }^{183}$ Congress also clarified that the waters above the outer continental shelf shall continue to be classed as "high seas," and that accordant navigation and fishing rights were preserved. ${ }^{184}$ The 1978 amendments also echo many of the concerns Congress addressed in other statutes passed around that time concerning the importance of protecting "marine, coastal, and human environments" impacted by offshore activities. ${ }^{185}$

OCSLA's withdrawal authority is housed in section 1341, entitled "Reservation of Land and Rights," which authorizes the President, "from time to time," to "withdraw from disposition any of the unleased lands of the outer Continental Shelf." ${ }^{186}$ It also provides authority to exercise a right of first refusal on offshore oil and gas in time of war, and reserves to the United States absolute federal ownership over all "fissionable materials" in the subsoil or seabed, including uranium. ${ }^{187}$ These provisions were part of the original statute enacted in $1953,{ }^{188}$ as was the withdrawal provision in section 1341(a). The latter is not conditioned on any notice, public comment period, or review of any type, and does not define any of the terms it contains in any further detail. ${ }^{189}$ Beyond the authority to withdraw submerged lands from mineral development and the right of first refusal in times of war, the remaining provisions of section 1341 relate to

\footnotetext{
18343 U.S.C. $\S 1332(3)-(6)$.

${ }^{184}$ Id. $1332(2)$.

${ }^{185} I d$. $\S 1332$ (6) (requiring operations to take precautions to insure against oil spills, fires, blowouts, and other hazards that "may cause damage to the environment or to property, or endanger life or health").

${ }^{186}$ Id. 1341(a). The Supreme Court has stated that "'the title of a statute and the heading of a section' are 'tools available for the resolution of a doubt' about the meaning of a statute." Almendarez-Torres v. United States, 523 U.S. 224, 234 (1998) (quoting Trainmen v. Baltimore \& Ohio R. Co., 331 U.S. 519, 528-529 (1947)). Thus, if there is ambiguity about the meaning of any portions of $\S 1341$, the title may help to resolve it.

${ }^{187} I d . \S 1341(\mathrm{~b}) \&(\mathrm{e})$.

${ }^{188}$ Id. Id. 1341.

${ }^{189} \mathrm{Id}$.; see also id. § 1331 (containing definitions of terms used in OCSLA).
} 


\section{Draft: Please do not cite without authors' permission}

To be published at 33 GEO. ENVTL. L. REV., IssuE \# 2

national security concerns, although these provisions skew towards federal retention of mineral rights, and they provide options for further Presidential restrictions on development activities, rather than the authority to revoke such prohibitions. ${ }^{190}$ Unlike FLPMA, OCSLA is silent with regard to Executive Branch authority to modify or revoke existing withdrawals. ${ }^{191}$

Since OCSLA's passage in 1953, presidents from have used its authority to withdraw submerged lands of the continental shelf, thereby prohibiting all mineral exploration or leasing activities in the withdrawn areas. ${ }^{192}$ In each withdrawal, the President enunciated a purpose of protecting submerged lands, and species or ecosystems dependent upon the surrounding waters, from the harmful effects of offshore drilling. ${ }^{193}$ Because OCSLA does not impose temporal limits on the President's authority to withdraw submerged lands, many of these withdrawals were permanent $a b$ initio. ${ }^{194}$ That is to say, although the text of the presidential withdrawal orders did not always specify that the withdrawals were permanent in nature, this was the legal effect of their creation. ${ }^{195}$

When an executive withdrawal under OCSLA was not intended to be permanent, explicit language limiting its duration was included in the withdrawal document. One such withdrawal was President George H.W. Bush's 1990 Statement on Outer Continental Shelf Oil and Gas Development Under OCSLA, ${ }^{196}$ which withdrew areas off the coast of California, Oregon, and Washington, and in the eastern portion of the Gulf of Mexico, to "allow time for additional studies" about the size of the reserves and to address "environmental and scientific concerns"

\footnotetext{
${ }^{190} I d . \S 1341(\mathrm{~b})-(\mathrm{f})$.

${ }^{191}$ League of Conservation Voters v. Trump, 363 F. Supp. 3d 1013, 1027 (D. Alaska 2019).

${ }^{192}$ Leske, supra note 71 , at 12-13.

${ }^{193} \mathrm{Id}$. at 13.

${ }^{194} \mathrm{Id}$. at 14.

${ }^{195} \mathrm{Id}$. at 13. For instance, President Eisenhower's 1960 withdrawal creating the Key Largo Coral Reef Preserve did not contain a termination date, and thus was permanent. $I d$.

${ }^{196}$ Id. at 14-15.
} 


\section{Draft: Please do not cite without authors' permission}

To be published at 33 GEO. ENVTL. L. REV., IssuE \# 2

that had been raised about potential drilling activities. ${ }^{197}$ President Bush specifically withdrew the areas off the Washington coast until 1996, or potentially longer if the studies did not "satisfactorily address" the enumerated concerns. ${ }^{198}$ Both Presidents Bush and Clinton issued orders withdrawing offshore areas under OCSLA, which included qualifying statements that the withdrawals were "subject to revocation." Nevertheless, these invocations of authority to revoke prior withdrawals were arguably unlawful given the lack of authority in OCSLA to revoke withdrawals, although the orders were never challenged in court. ${ }^{199}$

Some executive orders pursuant to OCSLA section 1341 defied easy categorization. For instance, in 2008, President George W. Bush issued an executive order imposing a temporary "delay" on offshore drilling, preventing development that would have been allowed under prior withdrawals made by Presidents George H.W. Bush and Bill Clinton. ${ }^{200}$ However, the initial delay later became a permanent prohibition on drilling because of a subsequent congressional act that permanently withdrew the affected lands from mineral leasing and development. ${ }^{201}$ In this way, the initial withdrawals were in aid of pending legislation, similar to the fact pattern in Midwest Oil.

The most extensive withdrawals of submerged lands under OCSLA occurred during President Obama's administration. ${ }^{202}$ President Obama first withdrew an area of submerged lands in Bristol Bay, Alaska, in the easternmost portion of the Bering Sea, in 2010. ${ }^{203}$ In 2014, he expanded the 2010 withdrawal to include all of the submerged lands underlying the North

\footnotetext{
197 Id at $14-15$.

${ }^{198} I d$. at 15.

${ }^{199}$ Id. at 15, 16 (quoting George W. Bush Statement on Outer Continental Shelf Oil and Gas Program for 1992-1997 (Aug. 4, 1992) \& William J. Clinton Memorandum on Withdrawal of Certain Areas of the United States Outer Continental Shelf from Leasing Disposition, 1 Pub. Papers 945 (June 12, 1998)).

${ }^{200} \mathrm{Id}$. at 17.

${ }^{201}$ Id. at 17; see also League of Conservation Voters, 363 F. Supp. 3d at 1021 n. 41.

${ }^{202}$ Leske, supra note 71 , at 18.

${ }^{203} \mathrm{Id}$.
} 


\section{Draft: Please do not cite without authors' permission}

To be published at 33 GEO. ENVTL. L. REV., ISSUE \# 2

Aleutian Basin Planning Area, which encompassed all of Bristol Bay. ${ }^{204}$ In 2015 and 2016, he issued executive orders withdrawing further isolated sections within two different planning areas north of Bristol Bay, in the Norton and St. Matthew-Hall Planning Areas, thus protecting most of the Bering Sea coast off of Alaska from offshore drilling. ${ }^{205}$ In his final days in office in 2016, President Obama issued two executive orders making his largest OCSLA withdrawals, totaling approximately 119 million acres, which encompassed vast areas of the continental shelf in the North Atlantic Ocean and the Chukchi and Beaufort Seas. ${ }^{206}$

The North Atlantic order stated that the affected area was withdrawn "from disposition by leasing for a time period without specific expiration" 207 and prohibited "consideration of this area for any future mineral leasing for purposes of exploration, development, or production," although it did not apply to existing leases. ${ }^{208}$ President Obama's stated rationale for the withdrawal was that it was consistent with the degree of "public stewardship entrusted" to his office, and served the purpose of protecting critical habitat areas "for marine mammals, deep water corals, other wildlife, and wildlife habitat, and to ensure that the unique resources associated with these canyons remain available for future generations." 209

The final Obama Alaskan executive order protected submerged lands in the Chukchi and Beaufort Seas for marine mammal habitat, "other wildlife, ... scientific research, and

\footnotetext{
${ }^{204} \mathrm{Id}$.

205 Id. at 19.

206 Id. at 20 .

${ }^{207}$ Presidential Memorandum - Withdrawal of Certain Areas off the Atlantic Coast on the Outer Continental Shelf from Mineral Leasing (Dec. 20, 2016), https://obamawhitehouse.archives.gov/the-pressoffice/2016/12/20/presidential-memorandum-withdrawal-certain-areas-atlantic-coast-outer. The area included "the Outer Continental Shelf (OCS) associated with 26 major canyons and canyon complexes offshore the Atlantic coast lying within areas currently designated by the Bureau of Ocean Energy Management as the North Atlantic and Mid-Atlantic Planning Areas." Id.

${ }^{208} I d$.

${ }^{209} I d$.
} 


\section{Draft: Please do not cite without authors' permission}

To be published at 33 GEO. ENVTL. L. REV., IssuE \# 2

Native Alaskan subsistence use. ${ }^{210}$ In terms similar to those found in his North Atlantic withdrawal order, President Obama cited the need to protect "the important, irreplaceable values of the Chukchi Sea and portions of the Beaufort Sea for marine mammals, other wildlife, [and] wildlife habitat." ${ }^{211} \mathrm{He}$ also identified "the vulnerability of these ecosystems to an oil spill," especially in light of the "unique logistical, operational, safety, and scientific challenges and risks of oil extraction and spill response in these Arctic waters." ${ }^{212}$ Like the North Atlantic withdrawal, the Alaskan waters withdrawal was to last "for a time period without specific expiration," which would "prevent[] consideration of [the] withdrawn areas for any mineral leasing for purposes of exploration, development, or production." ${ }^{213}$

Shortly after taking office in January 2017, and consistent with his America First Energy Policy, ${ }^{214}$ President Trump issued Executive Order 13795, which purported to "modify" the December 2016 Obama withdrawals. Specifically, Executive Order 13795 proclaimed that:

The body text in each of the memoranda of withdrawal from disposition by leasing of the United States Outer Continental Shelf issued on December 20, 2016, January 27, 2015, and July 14,2008 , is modified to read, in its entirety, as follows:

"Under the authority vested in me as President of the United States, including section 12(a) of the Outer Continental Shelf Lands Act, 43 U.S.C. 1341(a), I hereby withdraw from disposition by leasing, for a time period without specific expiration, those areas of the Outer Continental Shelf designated as of July 14, 2008, as Marine Sanctuaries under the Marine Protection, Research, and Sanctuaries Act of 1972, 16 U.S.C. 1431-1434, 33 U.S.C. 1401 et seq." 215

\footnotetext{
${ }^{210}$ Presidential Memorandum - Withdrawal of Certain Portions of U.S. Arctic Outer Continental Shelf from Mineral Leasing (Dec. 20, 2016), https://obamawhitehouse.archives.gov/the-press-office/2016/12/20/presidentialmemorandum-withdrawal-certain-portions-united-states-arctic.

${ }^{211} I d$.

${ }^{212} I d$.

${ }^{213} I d$.

${ }^{214}$ See supra notes 1-31 and accompanying text.

${ }^{215}$ Exec. Order No. 13,795, Implementing an America-First Offshore Energy Strategy, 82 Fed. Reg. 20815 (May 3, 2017) (emphasis added).
} 


\section{Draft: Please do not cite without authors' permission}

To be published at 33 GEO. ENVTL. L. REV., IssuE \# 2

Trump's executive order styled the revocation of President Obama's earlier withdrawal actions as a "modification," rather than a revocation. ${ }^{216}$ Elsewhere in the order, however, President Trump did purport to "revoke" an Obama executive order concerning climate change resilience as a means of "streamlin[ing] existing regulatory authorities." 217 The revoked Obama order had withdrawn from leasing, "for a time period without specification," areas of the outer continental shelf off the Alaska coast pursuant to section 1341 of OCSLA in order to further "the principles of responsible public stewardship entrusted to this office and [taking] due consideration of the importance of the withdrawn area to Alaska Native tribes, wildlife, and wildlife habitat, and the need for regional resiliency in the face of climate change." ${ }^{218}$

The 2017 Trump revocation was the first OCSLA revocation to land in court and it did not fare well. ${ }^{219}$ In the complaint challenging it, several environmental groups alleged first that section 5 of Trump's order constituted an act "in excess of [presidential] authority under Article II of the U.S. Constitution and intruded on Congress's non-delegated exclusive power under the Property Clause, in violation of the doctrine of separation of powers." ${ }^{220}$ Second, plaintiffs alleged that section 5's purported modification of President Obama's withdrawal, unsupported by the text of OCSLA, was an unlawful ultra vires act. ${ }^{221}$ In response, the government argued that "[t]he President possesses broad discretionary power under OCSLA to modify the withdrawal of areas from exploration or development, and he also has authority under Article II, which was exercised by President Truman first to claim and later to reserve the OCS as a

\footnotetext{
${ }^{216} I d . \S 5$.

${ }^{217}$ Id. § 4(c) (revoking Exec. Order No. 13754, Northern Bering Sea Climate Resilience, 81 Fed. Reg. 90669 (Dec. 9, 2016)).

${ }^{218}$ Exec. Order No. 13754, supra note 217, § 3.

${ }^{219}$ League of Conservation Voters v. Trump, 363 F. Supp. 3d 1013 (D. Alaska 2019).

${ }^{220}$ Compl., 9 60, in League of Conservation Voters v. Trump, 363 F. Supp. 3d 1013, 2017 WL 1736693 (D. Alaska) (filed May 3, 2017).

${ }^{221} I d$. at $\uparrow \uparrow$ 64-65.
} 


\section{Draft: Please do not cite without authors' permission}

To be published at 33 GEO. ENVTL. L. REV., ISSUE \# 2

petroleum reserve."222 The OCSLA argument was based upon a line of reasoning that the language "from time to time" in that statute rendered it ambiguous, and therefore, subject to interpretation by the President. ${ }^{223}$ The Article II argument was based on the fact Truman had first withdrawn the outer continental shelf lands from mineral development pursuant to his authority under Article II of the Constitution, and notwithstanding Congress's subsequent passage of OCSLA in 1953, President Trump retained the authority to "undo" Truman's withdrawal using the same authority that created it. ${ }^{224}$

In its analysis of the textual argument, the court found it significant that section 1341 "refers only to the withdrawal of lands." 225 In the court's view, Congress "expressed one concept — withdrawal—and excluded the converse — revocation." ${ }^{226}$ Moreover, the court viewed the statutory phrase "from time to time" as a clarification of the scope of the President's withdrawal authority only; it affords a President the discretion to withdraw lands at any time and for discrete periods, but "does not specifically give the President the authority to revoke a prior withdrawal." ${ }^{227}$ Disagreeing with the government's position that the President is " the exclusive judge' of determining the OCS lands subject to leasing," the court recognized that this "power ultimately is vested in Congress under the Property Clause." ${ }^{228}$ Nor did section 1341(a)'s authorization to make withdrawals "from time to time" clearly signify that no withdrawals are

\footnotetext{
${ }^{222}$ Fed. Defs.' Mem. in Support of Mot. for Summary Judgment, p. 22, in League of Conservation Voters v. Trump, 363 F. Supp. 3d 1013, 2018 WL 3969624 (D. Alaska) (filed July 18, 2018) ("In Executive Order 13795, the President invoked the full delegated authority that Congress granted him in OCSLA, as well as his inherent constitutional authority under Article II.”).

${ }^{223} \mathrm{Id}$. at 23.

${ }^{224}$ Fed. Defs.' Reply Mem. in Support of Mot. for Summary Judgment, p. 6, in League of Conservation Voters v. Trump, 363 F. Supp. 3d 1013, 2018 WL 5263320 (D. Alaska) (filed Oct. 5, 2018) ("The President's broad authority to revisit, reverse, and undo prior decisions of the Executive Branch is inherent in the powers of the office vested by the Constitution.").

${ }^{225}$ League of Conservation Voters, 363 F. Supp. 3d at 1021.

${ }^{226} \mathrm{Id}$.

${ }^{227} I d$.

${ }^{228}$ Id. at 1023.
} 


\section{Draft: Please do not cite without authors' permission}

To be published at 33 GEO. ENVTL. L. REV., ISSUE \# 2

permanent, such that they are necessarily subject to presidential revocation. ${ }^{229}$ An alternative reading would give the President authority to make discrete withdrawals "at any time and for discrete periods of time, as well as make withdrawals that extend indefinitely into the future."230 Because the court characterized the statute as ambiguous, it examined the language of section 1341 in the context of the entire statute to clarify the statutory reference to "from time to time. ${ }^{231}$

The court concluded that OCSLA's structure indicates that Congress intended for section 1334 to release lands for offshore mineral development and for section 1341 to serve as a protective mechanism, giving the President the authority to prohibit such development in specific locations. ${ }^{232}$ This reading gives effect to each provision of the statute, rendering none "inoperative or superfluous." ${ }^{233}$ The court noted that under the Property Clause of the Constitution, Congress has the authority to determine in the first instance whether and which offshore lands shall be open to mineral leasing. ${ }^{234}$ It followed, then, that if Congress chose to delegate the authority to withdraw and revoke prior withdrawals to the President, that would be Congress's choice to make. But the court reasoned, "Congress's silence in Section [1341(a)] as to according the President revocation authority was likely purposeful; had Congress intended to grant the President revocation authority, it could have done so explicitly, as it had previously done in several (but not all) of its previously enacted uplands laws." ${ }^{235}$ Accordingly, the court

\footnotetext{
${ }^{229} \mathrm{Id}$. at 1024.

${ }^{230} \mathrm{Id}$.

${ }^{231} I d$.

${ }^{232} \mathrm{Id}$. at 1025.

${ }^{233} \mathrm{Id}$.

${ }^{234} \mathrm{Id}$. at 1023.

${ }^{235} \mathrm{Id}$. at 1027 . The court did not address the government's argument regarding Article II authority, basing its ruling entirely upon statutory interpretation.
} 


\section{Draft: Please do not cite without authors' permission}

To be published at 33 GEO. ENVTL. L. REV., IssuE \# 2

invalidated President Trump's executive order and restored President Obama’s 2016

withdrawals. ${ }^{236}$

The congressional restraint on Executive authority to "modify" or otherwise alter prior Executive OCSLA withdrawals becomes even clearer after a thorough review of FLPMA's companion provisions.

\section{B. Onshore Public Mineral Development and the Development of the Federal Land Policy and Management Act.}

Through much of the twentieth century, the proper locus of control over the management of federal lands and resources was a bone of contention, and the resulting controversies implicated both federalism and separation of powers concerns. The federal government and the coastal states laid conflicting claims of ownership to offshore resources, especially mineral resources. The battle over control of onshore mineral resources was waged between Congress and the Executive branch. The Supreme Court intervened in both, recognizing primacy of federal control over offshore resources located more than three miles offshore ${ }^{237}$ and endorsing implied presidential power to withdraw federal lands. ${ }^{238}$ These decisions failed to entirely quell the controversies, however, leaving it to Congress to provide clearer enunciations of the scope of each sovereign's, and each branch's, authorities. Congress answered this call with respect to onshore federal lands by passing FLPMA in $1976 .{ }^{239}$

\footnotetext{
${ }^{236} I d$. at 1031 . The court only invalidated $\S 5$ of the order, which purported to "modify" the Obama withdrawals, not $\S 4(c)$, which purported to "revoke" the Obama executive order on climate resilience. The plaintiffs' complaint only requested invalidation of $\S 5$, see League of Conservation v. Trump, Complaint for Declaratory and Injunctive Relief, at Prayer for Relief, $\uparrow 1,2017$ WL 1736693 (D. Alaska), so the court had no need to address the validity of $\S$ 4(c). The court's reasoning would have supported invalidation of $\S 4(\mathrm{c})$ as well. If Congress's failure to delegate revocation authority to the President precluded "modification" of President Obama's withdrawal memorandum, it also precluded revocation of his climate executive order and the withdrawals it made.

${ }^{237}$ See supra notes 165-174 and accompanying text (discussing cases resolving disputes over resources off the California and Gulf coasts).

${ }^{238}$ See supra notes 106-130 and accompanying text (discussing Midwest Oil v. United States).

23943 U.S.C. $\S \S 1701-1787$.
} 


\section{Draft: Please do not cite without authors' permission}

To be published at 33 GEO. ENVTL. L. REV., IssuE \# 2

FLPMA's provisions affecting mineral development on the federal lands are perhaps best viewed within the context of the general shift in federal policy over the course of the twentieth century concerning management of all onshore public natural resources. As the discussion above indicates, ${ }^{240}$ federal natural resource management policy replaced disposal with retention and a greater degree of resource and land conservation starting with the first Roosevelt administration. ${ }^{241}$ The shift to retention was more complex for onshore than offshore resources due to the extensive body of existing federal legislation relating to onshore lands and natural resources, the private inholdings and rights in public lands (including vast mineral rights obtained under statutes like the General Mining Law), ${ }^{242}$ and the changing priorities of presidential administrations, especially with respect to mineral development on federal lands, between 1900 and 1976. The ad hoc nature of executive exercises of the withdrawal power between 1910 and 1976 resulted in "a crazyquilt of new and old withdrawals and classifications, many of which were overlapping and obsolete." ${ }^{243}$ FLPMA clarified this confusion, once and for all.

\section{FLPMA'S Legislative History - the Public Lands Law Commission Report}

Unlike OCSLA, whose passage was compelled by tension between the coastal states and the federal government, FLPMA's passage was a direct result of the recommendations provided in the Public Land Law Review Commission Report (PLLRC). ${ }^{244}$ Congress established the

\footnotetext{
${ }^{240}$ See supra note 94 and accompanying text.

2411 CoGGINS \& GLICKSMAN, supra note 39, $\S 2: 12-2: 15$.

${ }^{242}$ George Cameron Coggins \& Margaret Lindberg Johnson, The Law of Public Rangeland Management II: The Commons and the Taylor Act, 13 ENVTL. L. 1, 4 (1982) ("Between 1789 and 1976, the United States sold and gave away well over a billion acres of land.").

${ }^{243}$ Coggins \& Nagel, Watt, supra note 51, at 506.

${ }^{244}$ Glicksman, Severability, supra note 85, at 70 ("FLPMA was designed to implement many of the recommendations of the PLLRC Report . . ..”); cf. Robert L. Glicksman \& George Cameron Coggins, Hardrock Minerals, Energy Minerals and Other Resources on the Public Lands: The Evolution of Federal Natural Resources Law, 33 TUlSA L.J. 765, 786 (1998) [hereinafter Glicksman \& Coggins, Hardrock Minerals] ("Congress never
} 


\section{Draft: Please do not cite without authors' permission}

To be published at 33 GEO. ENVTL. L. REV., ISSUE \# 2

PLLRC as a bipartisan independent agency in 1964 to review the various federal land laws, which had "developed over a long period of years through a series of Acts of Congress [and] which [we]re not fully correlated with each other." ${ }^{245}$ Because Congress determined that those laws might "be inadequate to meet the current and future needs of the American people and because administration of the public lands and the laws relating thereto has been divided among several agencies of the Federal Government," Congress commissioned "a comprehensive review of those laws and the rules and regulations promulgated thereunder ... to determine whether and to what extent revisions thereof are necessary." 246 In addition, by the 1960 s, interest in conserving natural resources had grown, prompting calls for more conservation-oriented federal land management policies. $^{247}$

After six years of study, the Commission produced its iconic report, One Third of the Nation's Land, in which it made numerous findings about the efficacy of existing laws and offered 137 specific recommendations to Congress concerning the future use and governance of federal lands. ${ }^{248}$ The report endorsed the fundamental principle that the federal government

adopted the recommendations of the Committee bodily. Many recommendations, however, were partially enacted in [FLPMA].").

${ }_{245}^{2}$ Pub. L. No. 88-606, § 2, 78 Stat. 902 (1964).

${ }^{246}$ Id,; see also Glicksman, Severability, supra note 85, at 69 ("The absence of a coherent framework for administration of [the public lands] lands prompted Congress to create a Public Land Law Review Commission ... in 1964."). Immediately before Congress formed the Commission, between 1956 and 1961, the Department of Interior engaged in a "vigorous program of [onshore] withdrawal review," resulting in a relatively significant number of revocations to previous withdrawals. PUBLIC LAND LAW REV. COMM'N, ONE THIRD OF THE NATION'S LAND: A REPORT TO THE PRESIDENT AND TO THE CONGRESS 6 (970) [hereinafter PLLRC Report].

${ }^{247}$ See Karin P. Sheldon \& Pamela Baldwin, Areas of Critical Environmental Concern: FLPMA's Unfulfilled Conservation Mandate, 28 Colo. NAT. Resources, ENERGY \& ENvTl L. ReV. 1, 18 (2017) ("The PLLRC . . supported the concepts embodied in the establishment and maintenance of the national forests, the National Park System, the National Wildlife Refuge System and other named conservation designations."); Jamison E. Colburn, Habitat and Humanity: Public Lands Law in the Age of Ecology, 39 ARIZ. ST. L.J. 145, 184 (2007) (concluding that the [PLLRC] clearly wished the multiple-use agencies would deepen their commitments to conservation"); $c f .1$ COGGINS \& GLICKSMAN, supra note 39, § 2:18 (referring to "the pathbreaking legislative developments in the 1960s," which led to "the deluge of revolutionary enactments of the 1970s," including public land management statutory revisions). But cf. Glicksman \& Coggins, Hardrock Minerals, supra note 244, at 786 ("Many claimed at the time (April 1970 saw the first Earth Day, remember) that the PLLRC Report was obsolete before it was released because it failed to take sufficient account of the environmental enthusiasm then prominent.").

${ }^{248}$ PLLRC Report, supra note 246, at ix, 1-288 (containing recommendations 1-137). 


\section{Draft: Please do not cite without authors' permission}

To be published at 33 GEO. ENVTL. L. REV., IssuE \# 2

needed to "provid[e] responsible stewardship of the public lands and their resources," 249 which must include "[e]nvironmental values," and protect these values "as major permanent elements of public land policy." 250

The Commission identified many flaws in the existing structure of federal lands laws, and in particular attributed chaotic decision making to the lack of clarity around the powers of Congress and the Executive. Specifically, the Commission found that "[t]he lack of clear statutory direction for the use of the public lands has been the cause of problems ever since Congress started to provide for the retention of some of the public domain in permanent Federal ownership." ${ }^{251}$ It added that the "relative roles of the Congress and the Executive in giving needed direction to public land policy have never been carefully defined[,]" and that the Executive had historically used its withdrawal authority in "an uncontrolled and haphazard manner."252 To clarify federal policy, the Commission's general recommendation was that

[t]he policy of large scale disposal of public lands reflected by the majority of statutes in force today should be revised and that future disposal should be only of those lands that will achieve maximum benefit for the general public in nonFederal ownership, while retaining in federal ownership those whose values must be preserved so that they may be used and enjoyed by all Americans. ${ }^{253}$

The Commission made several recommendations concerning the Executive power to withdraw and revoke prior withdrawals. ${ }^{254}$ Recognizing that withdrawals were part of a larger planning framework that was necessary to manage uses of federal lands and natural resources, the Commission suggested that Congress act expeditiously to address the "urgent" need to clarify the power to make the initial decisions about different land uses and the parameters within which

\footnotetext{
${ }^{249} I d$. at 7.

${ }^{250} \mathrm{Id}$.

${ }^{251} I d$. at 43 .

${ }^{252} \mathrm{Id}$.

${ }^{253} I d$. at 1 .

${ }^{254} \mathrm{Id}$. at $1-2$.
} 


\section{Draft: Please do not cite without authors' permission}

To be published at 33 GEO. ENVTL. L. REV., ISSUE \# 2

those decisions could be implemented. ${ }^{255}$ The Commission found that "virtually all of the public domain in all fifty states" had been withdrawn from entry under one or more of the federal land laws, but that determining which lands had been withdrawn from specific categories of entry was a task that could be done only with "great difficulty." ${ }^{256}$ In addition, the Commission found that "in many cases, there was hasty action" in making withdrawals, "based on preconceived determinations instead of being based on careful land use planning." ${ }^{257}$ In the Commission's view, these hasty and uninformed decisions had contributed to withdrawals that did not further any particular policy.

The Commission therefore urged Congress to undertake an "immediate review ... of all existing withdrawals, set asides, and classifications of public domain lands that were effected by Executive action" to determine whether the purposes for which those lands had been withdrawn was consistent with the standards identified in its report. ${ }^{258}$ It further recommended that Congress provide for a "careful review of 1) all Executive withdrawals and reservations and 2) BLM retention and disposal classifications under the Classification and Multiple-Use Act of 1964." ${ }^{259}$ Furthermore, the Commission concluded that "[l]arge scale limited or single use withdrawals of a permanent or indefinite term should be accomplished only by an act of Congress. ${ }^{260}$ The Commission also recommended cabining Executive withdrawal authority by expressly delegating it, "with statutory guidelines to insure proper justification for proposed

\footnotetext{
${ }^{255} \mathrm{Id}$. at 75 .

${ }^{256} I d$. at 52 .

${ }^{257} \mathrm{Id}$. at 1.

${ }^{258} \mathrm{Id}$. at 2 ; see also id. at 52.

${ }^{259} \mathrm{Id}$. at 52. Congress enacted the Classification and Multiple Use Act of 1964, Pub. L. No. 88-607, 78 Stat. 986, on the same day as it created the PLLRC "to provide interim guidance to the BLM pending issuance of the PLLRC's recommendations." Glicksman, Severability, supra note 85, at 69 n.401.

${ }^{260}$ PLLRC Report, supra note 246, at 54.
} 


\section{Draft: Please do not cite without authors' permission}

To be published at 33 GEO. ENVTL. L. REV., ISSUE \# 2

withdrawals, provide for public participation in their consideration and establish criteria for Executive action. ${ }^{261}$

The Commission's recommendation to clarify or cabin Executive authority in this area was based upon its recognition of the "exclusive authority" conferred to Congress in the Property Clause. ${ }^{262}$ Acknowledging that there had been, up to that point, "conflicting views" on the complex relationship between Executive and congressional authority over federal lands, including the authority to make, modify and revoke mineral withdrawals, the Commission deemed it "essential" for Congress to clarify and assert its own authority under the Property Clause, and delegate specific authority to the Executive where Congress deemed it necessary or efficacious. ${ }^{263}$ It urged Congress to "establish national policy in all public land laws by prescribing the controlling standards, guidelines, and criteria for the exercise of authority delegated to executive agencies." 264 In addition, the Commission suggested that

Congress assert its constitutional authority by enacting legislation reserving unto itself exclusive authority to withdraw or otherwise set aside public lands for specified limited purpose uses and delineating specific delegation of authority to the Executive as to the types of withdrawals and set asides that may be effected without legislative action. ${ }^{265}$

The Commission specifically recommended that any authority delegated to the Executive branch by Congress concerning withdrawals, "should be limited and exercised only within prescribed statutory guidelines."266

\footnotetext{
${ }^{261} I d$

${ }^{262} I d$.

${ }^{263}$ Id. at 54; see also id. at 42 (noting the Commission's belief "that the roles of both Congress and the administrative agencies must be more clearly defined so that the limits of the discretionary powers are understood by the administrators and the public").

${ }^{264} I d$. at 2.

${ }^{265} \mathrm{Id}$.

${ }^{266} I d$. at 55 .
} 


\section{Draft: Please do not cite without authors' permission}

To be published at 33 GEO. ENVTL. L. REV., ISSUE \# 2

The Commission further recommended that Congress clarify the Executive Branch's authority to modify or revoke prior withdrawals. ${ }^{267}$ Although Executive Branch authority already existed to review withdrawals, it had been exercised actively only during the period from 19561961, as noted above. ${ }^{268}$ The Commission therefore called on Congress to clarify the scope and nature of agency authority to modify or revoke previous withdrawals in several ways. ${ }^{269}$ First, according to the Commission, the Secretary of Interior's authority to "effect modifications or revocations" of withdrawals by an agency outside the Department should be limited. ${ }^{270}$ Existing authority vested "veto power" over the Secretary of Interior's recommendations in the other department head. ${ }^{271}$ The Commission recommended that Congress delegate exclusive power to revoke or modify an earlier withdrawal to the "same officer who is given the delegated authority to effect withdrawals." ${ }^{272}$ It also recommended periodic reporting by the land management agencies to Congress on the status of withdrawals under the jurisdiction of the various cabinet departments. ${ }^{273}$ Finally, the Commission recommended that Congress repeal or modify existing statutes that were inconsistent with the report's recommendations, even if the report itself did not specifically call for such specific changes in existing law. ${ }^{274}$

Following the submission of the Commission's Report to Congress, six years of legislative negotiations occurred as Congress attempted to respond to the Commission's

\footnotetext{
${ }^{267} I d$. at 56.

${ }^{268}$ See supra notes 134-138 and accompanying text.

${ }^{269}$ PLLRC Report, supra note 246, at 56.

${ }^{270} \mathrm{Id}$.

${ }^{271} I d$.

${ }^{272} \mathrm{Id}$.

${ }^{273} \mathrm{Id}$.

${ }^{274} \mathrm{Id}$. at xi ("It will be up to the Congress in framing new legislation, in those instances where an entire law would not be rendered obsolete, to determine whether there should be an amendment to, or replacement of, an existing law. The probability is that upon adoption of this Commission's recommendations, no public land law will be left intact.").
} 


\section{Draft: Please do not cite without authors' permission}

To be published at 33 Geo. EnVtL. L. ReV., ISSUE \# 2

recommendations. ${ }^{275}$ The Commission's support for cabining or clarifying executive withdrawal authority was hotly debated in the runup to adoption of FLPMA, with the Department of Interior weighing in to offer its perspective on the value of Executive withdrawal authority. ${ }^{276}$

Congressional committees squabbled over matters such as the definition of a withdrawal, ${ }^{277}$ the length of permissible withdrawals, and whether the new statute should include authority to revoke prior withdrawals. ${ }^{278}$ Despite the Commission's extensive discussion of the need to clarify revocation as well as withdrawal authority, the bills clarified only a few points about the latter, and none regarding the former. For instance, the bills clarified that the Secretary of Interior could not withdraw lands subject to the management authority of the Secretary of Agriculture, without consent. ${ }^{279}$ And it is clear from the legislative history that Congress intended for the "implied" executive authority to withdraw, recognized by the Court in Midwest Oil, to be

${ }^{275}$ Michael C. Blumm \& Andrew B. Erickson, Federal Wild Lands Policy in the Twenty-First Century: What A Long, Strange Trip It's Been, 25 Colo. NAT. ResourCeS, ENERGY \& ENVTL L. ReV. 1, 32 (2014).

${ }^{276}$ Congressional Record, H.R. 7211 and Its Impact Upon Wildlife Refuges, Letter from Secretary of Interior Rogers Morton to Hon. Wayne Aspinall, Chairman, House Committee on Insular Affairs, at 6583 (June 28, 1972).

Secretary Morton's view was that

The Executive withdrawal is an essential management tool to reconcile the many competing demands on the public domain and to preserve important public values against non-discretionary private appropriation: I do not contend that the Executive should have unlimited discretion in this area. I strongly believe that effective public land management requires mutual trust and cooperation between Congress and the Executive Branch. For a number of years the Department of the Interior has notified your Committee of all proposed withdrawals exceeding 5,000 acres. We have, moreover, used the withdrawal authority with restraint. In 1970, 96,924 acres were withdrawn while previous withdrawals on 964,961 acres were revoked.")

${ }^{277}$ E.g., H.R. REP. No. 94-1724, at 58, 1976 U.S.C.C.A.N. 6227, 6218:

The definition in Section 103(j) of this bill would plunge the law back into the chaotic situation at the turn of the century when no one knew exactly what a withdrawal meant. It would call everything from a land use plan, through a formal designation of use, to a traditional withdrawal, a "withdrawal." This bears little or no relationship to the traditional concept of withdrawal to any Secretarial decision that a particular parcel of land should be used primarily for one purpose. This proposed definition represents a completely new concept; and if it is called a "withdrawal," it will only engender further confusion.

${ }^{278}$ The first appearance of what became FLPMA's provision conferring withdrawal, modification, and revocation authority was in H.R. 13777, $94^{\text {th }}$ Cong., 2d Sess., at 25 (May 13, 1976) (conferring authority to "make, modify, extend, or revoke withdrawals only in accordance with the provisions and limitations of this section.").

${ }^{279}$ Cong. Record, Proceedings and Debates of the $94^{\text {th }}$ Cong. on H.R. 13777, p. 175 (July 22, 1976). 


\section{Draft: Please do not cite without authors' permission}

To be published at 33 GEO. ENVTL. L. REV., ISSUE \# 2

revoked by the new law. ${ }^{280}$ At least one House Committee, Interior and Insular Affairs, related

concerns about the lack of clarity between sections 1712 (related to land-use planning) and 1714

(authorizing withdrawals, modifications, and revocations). It also noted that withdrawals which

were "not presently considered ... management decisions" under 1712 could "take on a new

meaning" as management decisions, subject to the requirements of that section, ${ }^{281}$ but failed to

elucidate what that "new meaning" was, or whether it believed that a management decision could

actually qualify as a withdrawal. ${ }^{282}$ But the Conference Report on the bill, which Congress

eventually passed into law as FLPMA, noted the lack of consensus between the House and

Senate committees on the scope of withdrawal and revocation authority, with the House

committees paying more attention to the need to clarify the scope of withdrawal authority than

their Senate counterparts. ${ }^{283}$ The House Report had noted the importance of retaining within

\footnotetext{
${ }^{280}$ H.R. REP. No. 94-1163, at 103 (1976) ("Effective on and after the date of approval of this Act, the implied authority of the President to make withdrawals and reservations resulting from acquiescence of the Congress (U.S. v. Midwest Oil Co., 236 U.S. 459) and the 5 following statutes and parts of statutes are repealed.")

${ }^{281}$ Those include reporting any management decision that excludes one or more of the principal or major uses for two or more years to Congress, which could then decide whether to exercise a legislative veto by concurrent resolution. Id. $\S 1712(\mathrm{e})(2)$. For further discussion of the status of FLPMA's legislative veto provisions, see infra notes 309-311 and accompanying text.

${ }^{282}$ H.R. REP. No. 94-1163, at 296. FLPMA defines a withdrawal, see 43 U.S.C. $§ 1702(j)$, but it does not define a management decision. The Supreme Court has noted that management decisions "are distinct from the [land use] plan itself," without providing further guidance. Norton v. S. Utah Wilderness Alliance, 542 U.S. 55, 69 (2004). The D.C. Circuit stated that "withdrawal revocations are themselves major management decisions" that are subject to $\S$ 1712's public participation requirements. Nat'l Wildlife Fed'n v. Burford, 835 F.2d 305, 322 (D.C. Cir. 1987), reh'g denied, 844 F.3d 889 (D.C. Cir. 1988). Cf. Yount v. Salazar, 933 F. Supp. 2d 1215, 1241 (D. Ariz. 2013), aff'd sub nom. Nat'1 Mining Ass'n v. Zinke, 877 F.3d 845 (9th Cir. 2017) (“Congress favored allowing the Executive to continue to make land-management decisions, including public land withdrawals, even while it repealed implied and statutory authority to do so."). On the other hand, FLPMA provides that "[w]ithdrawals made pursuant to section 1714 . . . may be used in carrying out management decisions.” 43 U.S.C. $§ 1712(\mathrm{e})(3)$. One court, construing this language, construed management decisions "by definition [to] cover 'mineral exploration and production." Pac. Legal Found. v. Watt, 529 F. Supp. 982, 996 (D. Mont. 1981), supplemented, 539 F. Supp. 1194 (D. Mont. 1982 ). Revocation of a withdrawal does not "carry out" a withdrawal. It does the opposite. $C f$. Douglas Timber Operators, Inc. v. Salazar, 831 F. Supp. 2d 285, 291 (D.D.C. 2011) (referring to "making land management decisions on the basis of the withdrawal decision").

${ }^{283}$ H.R. REP. No. 94-1724, at 58 (1976), reprinted in 1976 U.S.C.C.A.N. 6227, 6230 (noting that "the Senate bill contained no provisions relating to authority for withdrawals of public lands").
} 


\section{Draft: Please do not cite without authors' permission}

To be published at 33 GEO. ENVTL. L. REV., ISSUE \# 2

congressional control "the integrity of the great national resource management systems . . .."284

Ultimately, the House's approach prevailed. ${ }^{285}$

\section{FLPMA's Limited Delegation of Secretarial Withdrawal and Revocation Authority}

FLPMA's passage in 1976 created the first organic statute for the BLM as manager of the federal onshore lands and mineral estate, ${ }^{286}$ although some provisions deal with other federal land systems. ${ }^{287}$ One of Congress's several overarching goals in passing FLPMA was to repeal many of the laws governing disposal of federal lands and resources and create a new policy of retention. FLPMA's very first subsection declares a policy that "the public lands be retained in Federal ownership, unless, as a result of the land use planning procedure provided for in this Act, it is determined that disposal of a particular parcel will serve the national interest." ${ }^{288}$ The BLM must manage those lands and resources that are retained under a multiple-use, sustained yield management standard. ${ }^{289}$ To determine which of the authorized multiple use to authorize on particular public lands, FLPMA requires the Interior Secretary to "prepare and maintain on a continuing basis an inventory of all public lands and their resource and other values."290

In the first section of the statute, Congress declared that "the national interest will be best realized if the public lands and their resources are periodically and systematically inventoried and their present and future use is projected through a land use planning process. ..."291 To

\footnotetext{
${ }^{284}$ H.R. REP. No. 94-1163, at 9 (1976), reprinted in 1976 U.S.C.C.A.N. 6175, 6183.

${ }^{285}$ See infra notes 312-319 and accompanying text (describing FLPMA's provisions concerning withdrawals and revocations).

2861 COGGINS \& GLICKSMAN, supra note $39, \S 6: 16$. As used in FLPMA, the term "public lands" refers to lands managed by the BLM, and specifically excludes lands located on the Outer Continental Shelf. 43 U.S.C. § 1702(e). ${ }^{287}$ E.g., 43 U.S.C. $\$ \$ 1761-1769$ (concerning the issuance of rights-of-way in the national forests as well as the public lands).

${ }^{288} I d$. $\S 1701$ (a).

${ }^{289} I d$. $\S 1712(\mathrm{c})(1), 1732(\mathrm{a})$.

${ }^{290} I d . \S 1711(\mathrm{a})$.

${ }^{291} I d . \S 1701(\mathrm{a})(2)$.
} 


\section{Draft: Please do not cite without authors' permission}

To be published at 33 GEO. ENVTL. L. REV., IssuE \# 2

address the aftermath of more than a century of piecemeal land classifications and withdrawals, FLPMA requires the BLM to develop lands use plans "regardless of whether [the public lands] previously have been classified, withdrawn, set aside, or otherwise designated for one or more uses. ${ }^{~} 292$ Management of the federal lands must conform to land use plans. ${ }^{293}$ Congress directed the BLM, "in administering public land statutes and exercising discretionary authority granted by them, ... to establish comprehensive rules and regulations after considering the views of the general public." ${ }^{294}$ Reflecting the resource protection and conservation ethic that drove much of the legislation adopted during the "environmental decade," ${ }^{295}$ FLPMA requires that:

the public lands be managed in a manner that will protect the quality of scientific, scenic, historical, ecological, environmental, air and atmospheric, water resource, and archeological values; [and] ... where appropriate, will preserve and protect certain public lands in their natural condition; that will provide food and habitat for fish and wildlife and domestic animals; and that will provide for outdoor recreation and human occupancy and use. ${ }^{296}$

Finally, FLPMA requires the Secretary to provide opportunities for public involvement including, where appropriate, public hearings, to give all interested parties the opportunity to provide input on planned actions or decisions. ${ }^{297}$

To restore congressional control over the process of withdrawing federal lands, as the PLLRC had recommended, FLPMA repealed the implied Executive authority to make withdrawals recognized in Midwest Oil. ${ }^{298}$ The statute declares a policy that Congress "exercise its constitutional authority to withdraw or otherwise designate or dedicate Federal lands for

\footnotetext{
${ }^{292}$ Id. $\S 1712$ (a). See also id. § 1712(d) (stating that public land classifications in effect on the effective date of FLPMA would be "subject to review in the land use planning process").

${ }^{293} I d . \S 1732$ (a).

${ }^{294}$ Id. $\S 1701(\mathrm{a})(5)$.

${ }^{295}$ See Robert L. Glicksman et Al., ENVIRONMENTAl Protection: LAW AND Policy 65 ( $8^{\text {th }}$ ed. 2019).

29643 U.S.C. $\S 1701(\mathrm{a})(8)$.

${ }^{297}$ Id. $\S 1712(\mathrm{f})$.

${ }^{298}$ Pub. L. No. 94-579, § 704(a), 90 Stat. 2743, 2792 (1976); National Mining Assn., 877 F.3d at 856.
} 


\section{Draft: Please do not cite without authors' permission}

To be published at 33 GEO. ENVTL. L. REV., ISSUE \# 2

specified purposes and ... delineate the extent to which the Executive may withdraw lands without legislative action." ${ }^{299}$ As noted above, ${ }^{300}$ FLPMA provides that existing classifications of federal lands would be subject to review in the land use planning process, and authorizes the Interior Secretary to "modify or terminate any such classification consistent with such land use plans." 301 Section 1714 required the Secretary to review prior withdrawals in eleven western states to determine whether they were consistent with the statutory objectives of the laws under which they were withdrawn. ${ }^{302}$ The statute authorizes the Secretary to "make, modify, extend or revoke withdrawals," but only as specified in section $1714 .{ }^{303}$ That proviso was clearly included to reassert congressional control over the process of making or revoking withdrawals, consistent with the explicit statutory repeal of the implied presidential withdrawal authority recognized in Midwest Oil some sixty years previously. ${ }^{304}$

The rest of section 1714 lays out a series of specific limitations on the Secretary's authority to make or terminate withdrawals. Some of those are procedural in nature, including the requirement that the Secretary must publish a notice of the application in the Federal Register describing the extent to which the land is to be segregated while the Secretary considers the application. ${ }^{305}$ Publication of the notice has the effect of segregating the land immediately from the applicable public land laws, effectuating a sort of de facto withdrawal while the procedures are undertaken. ${ }^{306}$

\footnotetext{
29943 U.S.C. $\S 1701(\mathrm{a})(4)$.

${ }^{300}$ See supra notes 258-260 and accompanying text.

${ }^{301} I d . \S 1712(\mathrm{~d})$.

${ }^{302} \mathrm{Id}$. $\S 1714(l)$.

${ }^{303} I d$. $\S 1714$ (a) (also authorizing Secretary of Interior to delegate these powers, but only to officials within Secretary's office who have been appointed by the President, with advice and consent of Senate).

${ }^{304}$ See supra notes 106-119 and accompanying text.

30543 U.S.C. § 1714(b). Publication is not required for emergency withdrawals. Id. § 1714(e)(2).

${ }^{306} I d$.
} 


\section{Draft: Please do not cite without authors' permission}

To be published at 33 GEO. ENVTL. L. REV., IssuE \# 2

Some of the constraints are substantive. They differ depending on whether a withdrawal is a large-tract withdrawal, a small-tract withdrawal, or a withdrawal made for an emergency purpose. Congress reserved to itself the authority to make permanent withdrawals of large tracts (of 5,000 acres or more), ${ }^{307}$ allowing the Secretary to make unilateral withdrawals of large tracts only on a temporary basis for up to twenty years. ${ }^{308}$ The Secretary must notify Congress of any large-tract withdrawals, and the notice must, among other things, describe the parcel proposed to be withdrawn, explain its mineral value, identify stakeholder interests, and indicate whether any suitable alternative sites are available for the uses the withdrawal would displace. ${ }^{309}$ The statute purports to retain a legislative veto over large-tract withdrawals, ${ }^{310}$ but the Ninth Circuit held that this provision was unconstitutional in $2017 .{ }^{311}$

FLPMA authorizes the Interior Secretary, on his or her own motion or upon request by a department or agency head, to withdraw tracts of less than 5000 acres for whatever period deemed desirable for a "resource use," for not more than twenty years for any other use (including administrative, facility-location, or other proprietary uses), and for not more than five years to preserve the tract for a specific use under congressional consideration. ${ }^{312}$ The Secretary may make an emergency withdrawal if he or she determines, or upon notification by an appropriate congressional committee, "that an emergency exists and that extraordinary measures must be taken to preserve values that would otherwise be lost." ${ }^{313}$ The Secretary must notify

\footnotetext{
307 See National Mining Assn., 877 F.3d at 863 (construing $§ 1714(\mathrm{c})$ )).

30843 U.S.C. $\S 1714(\mathrm{c})$; Nat'l Mining Ass'n, 877 F.3d at 856.

30943 U.S.C. $\$ 1714(\mathrm{c})(2)$.

${ }^{310}$ Id. $\S 1714(\mathrm{c})(1)$.

311 National Mining Assn., 877 F.3d at 861. For thorough analysis of the constitutionality of all of FLPMA's legislative veto provisions, see generally Glicksman, Severability, supra note 85.

31243 U.S.C. $\S 1714(\mathrm{~d})$.

${ }^{313}$ Id. $\S 1714(\mathrm{e})$.
} 


\section{Draft: Please do not cite without authors' permission}

To be published at 33 GEO. ENVTL. L. REV., ISSUE \# 2

Congress when making an emergency withdrawal, which may not exceed three years and is not eligible for an extension. ${ }^{314}$

FLPMA requires the Secretary to review both large-tract and small-tracts withdrawals with a specified period toward the end of the withdrawal period to determine whether they should be extended. ${ }^{315}$ Extensions must comply with statutory notification requirements and may be made "only if the Secretary determines that the purpose for which the withdrawal was first made requires the extension, and then only for a period no longer than the length of the original withdrawal period." 316

Read in light of the history of withdrawals discussed above, ${ }^{317}$ Congress' intent in imposing these limitations on Secretarial withdrawals becomes clearer. First, Congress intended to reassert its Property Clause authority over the public lands, and explicitly declare that Congress, not the Executive Branch, would be the sole repository of authority to permanently set aside large tracts of land and withdraw them from the operation of the other public land laws, including the mineral disposition laws. Second, the notification requirements regarding large tract withdrawals were designed to preclude surprise withdrawals, so that Congress could block those with which it disagreed. ${ }^{318}$

FLPMA also constrains Secretarial authority to modify or revoke withdrawals, but the scope of that authority is less clear. For one, section 1714(j) prohibits the Secretary from modifying or revoking any congressional withdrawal of any national monument created by

\footnotetext{
${ }^{314} \mathrm{Id}$.

${ }^{315} \mathrm{Id} . \S 1714(\mathrm{f})$.

${ }^{316} \mathrm{Id}$.

317 See supra Part 1.

${ }^{318}$ Given the unconstitutionality of the statutory legislative veto mechanisms, the only way for Congress to block Secretarial withdrawals that meet the procedural and substantive requirements of $\S 1714$ is to enact legislation overturning them, and then only if the President signs the legislation or Congress is able to override a presidential veto.
} 


\section{Draft: Please do not cite without authors' permission}

To be published at 33 GEO. ENVTL. L. REV., ISSUE \# 2

presidential proclamation pursuant to the Antiquities Act, or any withdrawal that added lands to the National Wildlife Refuge System before FLPMA's adoption or pursuant to the terms of FLPMA. ${ }^{319}$ Other sections of FLPMA also impose restraints on the Secretarial authority to revoke withdrawals. One of these was analyzed in National Wildlife Federation v. Burford, ${ }^{320}$ which involved a challenge to a large-scale revocation by President Reagan's Interior Secretary of withdrawals on over 180 million acres of federal lands in seventeen states. ${ }^{321}$ The National Wildlife Federation (NWF) challenged Secretary Watt's comprehensive reclassification and revocation program under FLPMA, NEPA, and the Administrative Procedure Act (APA). ${ }^{322}$ The district court enjoined the Secretary's actions based on its analysis of the plaintiff's likelihood of success on the merits and the great public interest at stake in the vast areas of federal lands that were losing protection from mineral development. ${ }^{323}$ Although the complaint alleged broadly that the reclassifications and revocations violated FLPMA, and the district court granted a preliminary injunction of the Secretary's order, the D.C. Circuit limited its interlocutory review to one issue: whether the Secretary violated FLPMA's public participation requirements by revoking the prior withdrawals without holding a hearing or otherwise seeking public input or comment. $^{324}$

To determine whether the Secretary was required to seek public comment prior to revoking withdrawals under section 1714(a), the court analyzed FLPMA's purposes and section

\footnotetext{
31943 U.S.C. $\S 1714(\mathrm{j})$.

320835 F.2d 305, 307 (D.C. Cir. 1987). The subject of withdrawals was also at the heart of the claims asserted by the plaintiff environmental groups in Lujan v. Nat'l Wildlife Fed'n, 497 U.S. 871, 890 (1990), but the Supreme Court limited itself to consideration of justiciability issues, holding that the groups lacked standing to sue. The Court did not address the merits of the legality of Interior Secretary Watt's alleged "land withdrawal review program."

${ }^{321}$ Burford, 835 F.2d at 309.

${ }^{322} \mathrm{Id}$.

${ }^{323}$ Id. at 310 .

324 The district court had focused its analysis of the plaintiff's request for injunctive relief on the Secretary's alleged noncompliance with the statutory public participation requirements. $I d$. at 319,322 .
} 


\section{Draft: Please do not cite without authors' permission}

To be published at 33 GEO. ENVTL. L. REV., IssuE \# 2

1712 planning requirements. It focused first on section 1714's requirement of public participation "in the Department's decision making." ${ }^{325}$ Noting that FLPMA "directs the Secretary to provide for public participation in 'the preparation and execution of plans and programs for, and the management of, the public lands, ${ }^{\prime 326}$ the court concluded that withdrawal revocations qualify as "management" decisions. ${ }^{327}$ Because the agency had not opened its largescale withdrawal revocations to public comment, the court affirmed the district court's ruling that the environmental groups had succeeded in showing a likelihood of success on their claim that, in revoking prior withdrawals, the agency violated FLPMA by failing to provide the required opportunity for public comment. ${ }^{328}$

Another, more recent decision confirms that the Secretary's withdrawal revocation authority is more limited than the plain text of section 1714(a) might suggest, and that a broader reading of the applicability of section 1714(a)'s "provisions and limitations" is the proper one. The issue in that case, National Mining Association v. Zinke, was whether former Secretary of Interior Ken Salazar violated FLPMA when he withdrew one million acres of public lands surrounding Grand Canyon National Park in 2012. ${ }^{329}$ A spike in the market for uranium and the threat of impending development of the vast uranium resource surrounding the Grand Canyon had created risks of increasing impairment to viewscapes within the park and potential contamination of area groundwater reserves. ${ }^{330}$ The Southern Paiute, Navajo, Hopi, Hualapai, and Havasupai tribes had requested the withdrawal to protect these values, along with "profound

\footnotetext{
${ }^{325} \mathrm{Id}$. at 319-20, 322 (quoting 43 U.S.C. § 1712(f)).

${ }^{326} I d$. at 322 (quoting 43 U.S.C. $§ 1739(\mathrm{e})$ ).

${ }^{327} I d$.

${ }^{328} I d$. at $322-23$.

${ }^{329}$ Nat'l Mining Ass'n v. Zinke, 877 F.3d 845, 856 ( $9^{\text {th }}$ Cir. 2017).

${ }^{330} \mathrm{Id}$. at 868 .
} 


\section{Draft: Please do not cite without authors' permission}

To be published at 33 GEO. ENVTL. L. REV., IssuE \# 2

and significan[t]" cultural values in the lands surrounding the Grand Canyon. ${ }^{331}$ After conducting a NEPA review, consulting with several affected counties in Arizona and Utah, and holding public meetings in the region, Salazar formalized the large-tract withdrawal. ${ }^{332}$

Several mining companies and local governments challenged the withdrawal as arbitrary and capricious and violative of FLPMA, arguing that FLPMA's large-tract withdrawal provision was unconstitutional. ${ }^{333}$ The district court, however, upheld the withdrawal. ${ }^{334}$ On appeal, the Ninth Circuit affirmed, issuing an expansive opinion exploring both the Secretary's large-tract withdrawal authority under FLPMA and constraints imposed on the exercise of that authority under the withdrawal provision's legislative veto. ${ }^{335}$ As noted above, ${ }^{336}$ the court invalidated the legislative veto provision, which it severed from the large-tract withdrawal authority provision, thus leaving that authority intact. ${ }^{337}$

Further, the court described the manner in which FLPMA “eliminates the implied executive branch withdrawal authority recognized in Midwest Oil, and substitutes express, limited authority." ${ }^{338}$ FLPMA "reserves to Congress the power to take certain land management actions, such as making or revoking permanent withdrawals of tracts of 5,000 acres or more ... from mineral extractions." ${ }^{\prime 39}$ According to the court, the statute's delegation to the Secretary of the power to make withdrawals is limited to temporary large withdrawals and temporary or permanent smaller withdrawals. ${ }^{340}$ Therefore, the analysis went, these withdrawals must be

\footnotetext{
${ }^{331} \mathrm{Id}$. at 869 .

${ }^{332} I d$. at 859 .

${ }^{333} \mathrm{Id}$. at 860 .

${ }^{334} \mathrm{Id}$. at 861 .

33543 U.S.C. $\S 1714(\mathrm{c})(1)$.

${ }^{336}$ See supra note 311 and accompanying text.

${ }^{337}$ Nat'l Mining Ass'n 877 F.3d at 866.

${ }^{338} \mathrm{Id}$. at 856.

${ }^{339} \mathrm{Id}$.

${ }^{340} \mathrm{Id}$.
} 


\section{Draft: Please do not cite without authors' permission}

To be published at 33 GEO. ENVTL. L. REV., ISSUE \# 2

consistent with the "values" expressed in FLPMA, given the statute's definition of a withdrawal. $^{341}$

To identify which public values and public purposes should be maintained, the court referred to FLPMA's environmental protection purpose statement:

[T]he public lands [should] be managed in a manner that will protect the quality of scientific, scenic, historical, ecological, environmental, air and atmospheric, water resource, and archeological values; that, where appropriate, will preserve and protect certain public lands in their natural condition; that will provide food and habitat for fish and wildlife and domestic animals; and that will provide for outdoor recreation and human occupancy and use. ${ }^{342}$

The court concluded that the Secretary acted within his discretion under section 1714(a) in making the large withdrawal to prevent uranium mining on the tracts at issue to protect viewscapes and cultural resources in the national park and to prevent potential groundwater contamination. ${ }^{343}$ The Ninth Circuit's construction of section 1714(a)'s withdrawal authority, which the court held was limited by the "public values" and "public purpose" statements in sections 1701 and 1702, supports the conclusion that the modification and revocation authority is similarly conditioned or limited, as we develop further below. ${ }^{344}$

\section{Chaos Further Resolved: The Demise of The Nonstatutory Presidential Practice of Making, Modifying, or Revoking Prior Withdrawals and CONGRESS'S Limited DELEgations OF AUTHORITy OVER WithDRAWALS IN OCSLA AND FLPMA}

\footnotetext{
${ }^{341} I d$. at 867 . FLPMA defines a withdrawal as the "withholding of an area . . from settlement, sale, location, or entry ... for the purpose of limiting activities under [the general land laws] in order to maintain other public values . .. or reserving the area for a particular public purpose ...." 43 U.S.C. $\S 1702(j)$.

343877 F.3d at 868 (noting that the agency's Record of Decision "concluded that unfettered mining presented a small but significant risk of dangerous groundwater contamination - a risk that would be substantially mitigated by the withdrawal. The final EIS supports this conclusion").

${ }^{344}$ See infra Part III(B).
} 


\section{Draft: Please do not cite without authors' permission}

To be published at 33 GEO. ENVTL. L. REV., IssuE \# 2

Over the years, Presidents have asserted various sources of authority both when seeking to protect federal lands for conservation or other purposes by withdrawing them from inconsistent uses and when attempting to modify or revoke the protections put in place by their predecessors. Some of these sources of authority have been statutory, while others have been nonstatutory. FLPMA repealed presidential nonstatutory withdrawal and revocation authority as Congress terminated its acquiescence in implied Executive Branch withdrawal authority. Instead, Congress put in place a carefully crafted new system of limited delegated authority. This Part begins by analyzing the repeal of nonstatutory Executive withdrawal, modification, and revocation authority and then analyzes what remains in the limited delegations contained in OCSLA and FLPMA.

\section{A. Nonstatutory Presidential Revocations on Federal Lands: A Relic of the Past}

Presidents have invoked nonstatutory authority in support of decisions to make, modify, or revoke withdrawals, styled alternately as "inherent Presidential authority" and as Constitutional authority directly derived from Article II. Yet, the judiciary has not recognized these claims as the basis for recognizing a separate form of Presidential "authority," instead observing only that Congress had from time to time acquiesced in this Presidential "practice." 345 In making the withdrawal at issue in Midwest Oil, President Taft cited Article II in support of his decision to withdraw the oil reserves that were being depleted for the benefit of the navy, consistent with his role as Commander-in-Chief of the military. ${ }^{346}$ In that case, however, the Court avoided ruling directly on whether Taft possessed the authority he claimed, resolving the case based on a recognition of the historical presidential "practice" of making withdrawals,

\footnotetext{
${ }^{345}$ Midwest Oil, 236 U.S. at 468.

${ }^{346}$ Id.
} 


\section{Draft: Please do not cite without authors' permission}

To be published at 33 GEO. ENVTL. L. REV., IssuE \# 2

combined with congressional acquiescence in the exercise of that practice for the previous eighty years. ${ }^{347}$ Midwest Oil is thus properly framed as a judicial recognition of an historical presidential "practice," subject to defeasance by Congress should it cease to acquiesce in the practice. $^{348}$

As discussed previously, Congress did in fact cease to acquiesce in the presidential practice recognized in Midwest Oil when it passed OCSLA and FLPMA. ${ }^{349}$ The former implicitly repealed the presidential practice by making an affirmative but limited delegation of authority regarding presidential withdrawals of offshore lands. ${ }^{350}$ The latter expressly repealed the presidential practice in $1976 .{ }^{351}$ While it might have been the case that, in President Truman's day, the Executive Branch could engage in the practice of withdrawing lands, resources, and minerals in the federal estate even in the absence of a statutory delegation of withdrawal authority, as recognized in Midwest Oil, OCSLA and FLPMA terminated both the practice and Congress's acquiescence in it. The same is true of the Executive practice of nonstatutory modifications and revocations of withdrawals, as will be further discussed below. ${ }^{352}$

OCLSA's repeal of the practice of presidential withdrawals of offshore lands is found in section 1341(a). In that provision, Congress delegated explicit withdrawal authority to the President, in the context of a fairly extensive framework of offshore mineral development allowed under the new statute. ${ }^{353}$ That section of OCSLA constitutes Congress's cessation of acquiescence in the presidential practice of making, modifying, or revoking offshore withdrawals

\footnotetext{
${ }^{347}$ Id. at 469.

348 Getches, supra note 63, at 280 (noting that prior to FLPMA's passage, “the executive's implied nonstatutory authority was construed to fill all the interstices around express delegations").

349 See supra notes 186-191, 298-316 and accompanying text.

35043 U.S.C. $\S 1341(\mathrm{a})$.

35143 U.S.C. $\S 1701(a)(4)$.

${ }^{352}$ See infra Part III(A).

35343 U.S.C. $\S 1341$ (a).
} 


\section{Draft: Please do not cite without authors' permission}

To be published at 33 GEO. ENVTL. L. REV., ISSUE \# 2

without congressional authorization and a replacement of the prior regime with an exclusively statutory one. Yet, despite this clear repudiation from Congress in OCSLA, President Trump invoked nonstatutory "authority” to modify (or revoke) President Obama’s OCSLA withdrawal in 2017. ${ }^{354}$ Trump's argument, in the League of Conservation Voters litigation, was that since President Truman had invoked Article II to withdraw the submerged lands of the outer continental shelf in 1945, Trump could modify President Obama's 2016 statutory withdrawal under OCSLA in 2017 using the same source of authority as Truman had invoked. ${ }^{355}$

There are several flaws in this argument, though. For one, if constitutional authority to revoke a prior withdrawal exists, it must be derived from, and related to, the President's role as Commander-in-Chief or some other Article II power. ${ }^{356}$ The President cannot revoke a predecessor's withdrawals to promote purposes such as achieving "energy dominance" if those purposes have nothing to do with presidential powers articulated in Article II. The Supreme Court roundly rejected a similar argument in the famous Youngstown Sheet \& Tube case in 1952, noting that a prior presidential action engaged in "without congressional authority" or express constitutional authority does not imbue a President's ultra vires act with the imprimatur of constitutionality, no matter how compelling the factual circumstances in which it was carried out. ${ }^{357}$

\footnotetext{
${ }^{354}$ Fed. Defs.' Mem. in Support of Mot. for Summary Judgment, supra note 222, at pp. 2-3.

${ }^{355} \mathrm{Id}$. In support of this theory, the Trump Justice Department argued that "[s[ince first asserting jurisdiction over the OCS, the United States has viewed the authority to manage the mineral resources of the Shelf as stemming from both the Property Clause and the President's Article II authority." Id. at 3 (citing 1988 Office of Legal Counsel memorandum concluding that "the President's constitutional power as the representative of the United States in foreign relations includes the authority to claim portions of the sea for the United States for purposes of international law....").

${ }^{356}$ Harold J. Krent, Distinguishing Between Core and Peripheral Presidential Powers, 94 CHI.-Kent L. REV. 553, 554 (2019) (internal citations and quotations omitted).

${ }^{357}$ Youngstown Sheet \& Tube Co. v. Sawyer, 343 U.S. 579, 588-89 (1952).
} 


\section{Draft: Please do not cite without authors' permission}

To be published at 33 GEO. ENVTL. L. REV., IssuE \# 2

Second, there is at least a plausible, if not strong, argument that even if nonstatutory presidential authority to make withdrawals in aid of pending legislation or for another compelling reason related to the President's Constitutional role once existed, Presidents have never had constitutional authority to revoke withdrawals ${ }^{358}$ While there is at least arguable support for some degree of nonstatutory presidential authority to preserve federal lands and resources, supported by the facts and reasoning in Midwest Oil, there is no similar arguable support for nonstatutory presidential revocation authority, which would completely undermine the purposes that the Court relied on in recognizing withdrawal authority. In the face of a national crisis stemming from a shortage of oil, the Court recognized President Taft's authority to withdraw public minerals to prevent the Navy from being forced to buy back federal oil at astronomical prices during a war. Not only was the President was essentially best suited to protect the public resource under threat; Congress was also on the brink of enacting a statute that would accomplish the same goal. Those justifications for recognizing nonstatutory presidential withdrawals authority would not apply to presidential efforts to dispose of federal lands and resources, especially if done unilaterally and unconnected to any pending legislative effort. ${ }^{359}$ Had the Court considered the constitutional issue in Midwest Oil, it is possible that it would have found Taft's withdrawal to be within his Article II powers, given the exigent circumstances facing the Navy, and his role as Commander-in-Chief. It is also possible, however, that the Court would have concluded that Presidents lack Article II authority over the federal lands, at least in the absence of any other presidential function such as the Commander-in-Chief powers in Article II that relate to the use of federal lands, and in light of the explicit allocation of federal land

\footnotetext{
${ }^{358}$ Robert J. Delahunty, Federalism Beyond the Water's Edge: State Procurement Sanctions and Foreign Affairs, 37 Stan. J. Int'l L. 1, 49 (2001).

${ }^{359}$ Midwest Oil, 236 U.S. at 468.
} 


\section{Draft: Please do not cite without authors' permission}

To be published at 33 GEO. ENVTL. L. REV., IssuE \# 2

management authority to Congress in the Property Clause. Even if Presidential authority to specify permissible uses of federal lands may be inferred from other Article II powers, that authority might be limited to the making, not the modification or revocation, of withdrawals for the reasons illustrated in Midwest Oil. The withdrawal power was necessary in that case to protect federal resources during a national crisis, when the required legislative process to accomplish the same goal might take too long and the resource would be permanently lost or destroyed. ${ }^{360}$ Exercise of the power would be particularly critical for fragile or unique federal lands or resources that are unprotected by any statute conferring withdrawal authority whose loss would be permanent and irreplaceable. Recognition of nonstatutory revocation authority would create the very risk of irreversible resource loss that the exercise of nonstatutory withdrawal authority in Midwest Oil was meant to prevent.

Even assuming the existence of inherent Executive authority to withdraw, however, the authority may be subject to temporal limitations. Midwest Oil recognized executive authority to withdraw oil lands "in aid of pending legislation." 361 In that case, a temporary withdrawal allowed President Taft to protect the federal government's property in the face of crisis while Congress pursued legislation that would permanently secure critically important lands or resources. Absent both a crisis and pending legislation to address it, the argument for recognizing nonstatutory withdrawal authority is weaker.

Some scholars have analyzed Presidential authority under a framework of core versus peripheral powers, based on the framework established by the Court in Youngstown. ${ }^{362}$ Core powers are those that cannot be infringed by another branch without violating the separation of

\footnotetext{
${ }^{360}$ This line of reasoning is supported by Midwest Oil, in which the Court relied on Attorney General opinions endorsing the President's authority to withhold lands from sale at his discretion. Id. at 471-72.

${ }^{361}$ Id. at 484 (citing Pres. Procl., Temporary Withdrawal Order No. 5 (Sept. 27, 1900)).

362 E.g., Delahunty, supra note 358 , at 49.
} 


\section{Draft: Please do not cite without authors' permission}

To be published at 33 GEO. ENVTL. L. REV., IssuE \# 2

powers doctrine and infringements on these powers would be nearly per se unconstitutional.

Peripheral powers, on the other hand, are those incidental to, or derived from, core powers. There is disagreement, however, about the nature of the President's role with respect to the federal lands and mineral resources under this framework, complicated by the limited judicial exploration of this issue to date, especially by the Supreme Court. Some constitutional scholars label President Taft's withdrawal of the lands in Midwest Oil as a peripheral power, ${ }^{363}$ while others find that the President's role as "manager" of federal property somehow confers authority to prevent or allow mineral development on them. ${ }^{364}$ The source of any such authority is anything but obvious. The Constitution's Property Clause vests in Congress, not the President, the power to establish rules governing management of the federal lands, and even under a strong conception of the unitary executive, ${ }^{365}$ the President could only exercise authority over those lands and resources which had been delegated to him or to an agency within the Executive Branch. ${ }^{366}$ Any presidential effort to exercise withdrawal or revocation authority that Congress chose not to delegate would undermine, rather than "take Care that the Laws be faithfully executed." 367

Moreover, a careful reading of Midwest Oil belies the contention that the President has a "peripheral power" to manage the federal lands by making, modifying, or revoking withdrawals. As noted above, the Supreme Court in that case never analyzed the President's withdrawals

\footnotetext{
${ }^{363} \mathrm{Id}$.

${ }^{364}$ Harold J. Krent, Review of Delegation and Its Discontents, Power Without Responsibility, David Schoenbrod, 94 Colum. L. ReV. 710, 731 (1994); Thomas W. Merrill, Rethinking Article i, Section 1: From Nondelegation to Exclusive Delegation, 104 ColuM. L. Rev. 2097, 2138 (2004) (noting that the President has been "given broad inherent authority with respect to the management of territories").

${ }^{365}$ See, e.g., Seila Law LLC v. Consumer Fin. Prot. Bureau, No. 19-7, 2020 WL 3492641, at *4 (U.S. June 29, 2020) ('Under our Constitution, the 'executive Power' - all of it —is 'vested in a President,' who must 'take Care that the Laws be faithfully executed."').

${ }^{366}$ See Getches, supra note 63, at 286 (asserting that "arguments that the executive has some inherent constitutional authority to make withdrawals of public lands are without merit.").

${ }^{367}$ U.S. CONST. art. II, § 3.
} 


\section{Draft: Please do not cite without authors' permission}

To be published at 33 GEO. ENVTL. L. REV., ISSUE \# 2

under Article II. It avoided the constitutional question by labeling them as a "practice," rather than a "power," and one subject to repeal by Congress if it chose to cease acquiescing in that practice. ${ }^{368}$ Midwest Oil therefore does not support the existence of inherent Article II authority over federal lands either. ${ }^{369}$

The few Attorney General opinions to address this issue also support the conclusion that Presidents have never had inherent authority derived from Article II to make, modify, or revoke withdrawals. ${ }^{370}$ As early as 1862 , well prior to Midwest Oil, Attorney General Edward Bates opined that President Lincoln's authority over the lands containing Fort Armstrong in Arkansas was "derived ... not from any power over the public land inherent in his office, but from an express grant of power from Congress." "371 Subsequent Attorneys General reached the same conclusions - that the President lacks nonstatutory authority over federal lands of any kind. ${ }^{372}$

Although OCSLA's legislative history is scant, it is clear that Congress considered the scope of presidential authority in its deliberations leading to the adoption of FLPMA. Congress knew that it was addressing a "complex area of law" (withdrawals, modifications, and revocations) by passing FLPMA and decided to specify its intentions in the statutory purpose statement. ${ }^{373}$ FLPMA section 1701(a)(4) is explicit-FLPMA represented an "exercise of [Congress's] constitutional authority to withdraw or otherwise designate or dedicate Federal lands for specified purposes and ... [to] delineate the extent to which the Executive may

\footnotetext{
368 Midwest Oil, 236 U.S. at 471-72.

${ }^{369}$ See Getches, supra note 63, at 286.

${ }^{370}$ Leske, supra note 71, at 32 ("absent specific authority from Congress, the executive branch is not authorized to return land to the public domain or rescind prior withdrawals").

${ }^{371}$ Rock Island Military Reservation, 10 Op. Att'y Gen. 359-60 (1862).

${ }^{372}$ Leske, supra note 71, at 33-34; see Glicksman, Severability, supra note 85, at 14 n. 78 \& n. 80.

${ }^{373}$ H.R. REP. 94-1163, 52, 1976 U.S.C.C.A.N. 6175, 6226 (U.S. Dep't of Interior, Office of Secretary) (April 28, 1976) (noting that " $[\mathrm{t}]$ he draft would repeal the Pickett Act, 43 U.S.C. 141-142 (1970), and eliminate any implied Presidential withdrawal power" and that "[a] cursory analysis discloses that the proposed repealer would effectively resurrect the very issue underlying the Midwest Oil case: how much inherent withdrawal power does the Executive possess constitutionally?")
} 


\section{Draft: Please do not cite without authors' permission}

To be published at 33 GEO. ENVTL. L. REV., ISSUE \# 2

withdraw lands without legislative action." ${ }^{374}$ Congress clearly intended to cease acquiescing in whatever Executive Branch authority that prior congressional acquiescence had created to withdraw federal lands (and presumably to modify or revoke withdrawals, although the drafting of the purpose statement is imprecise on is scope) without legislative authorization or approval. ${ }^{375}$ If this provision left any doubt, section 704(a) of FLPMA eliminated it by repealing "the implied authority of the President to make withdrawals and reservations resulting from the acquiescence of the Congress (U.S. v. Midwest Oil, 236 U.S. 459)." 376

OCSLA's purpose statement is less clear on the question of inherent Executive withdrawal, modification, or revocation authority, but section 1341(a)'s detailed delegation of authority to the Executive only to withdraw lands speaks volumes. The government's argument in the League of Conservation Voters case that Article II is the source of independent revocation authority ignores the passage of OCSLA between Truman's original order withdrawing the OCS, and President Obama's 2016 withdrawal pursuant to OCSLA. The district court declined to address the constitutional question, finding that President Trump's order was unlawful because it exceeded his authority under OCSLA. But allowing the President, based on alleged inherent constitutional authority to do the opposite of what Congress has conferred upon him in a statutory delegation, would essentially usurp Congress's Property Clause authority. ${ }^{377}$ FLPMA's

\footnotetext{
37443 U.S.C. $§ 1701(a)(4)$ (emphasis added).

375 See Wisconsin Cent. R. Co. v. Price Cty., 133 U.S. 496, 504 (1890) (Congress's assertion of Property Clause authority "implies an exclusion of all other authority over the property which could interfere with this right or obstruct its exercise.")

${ }^{376}$ Pub. L. No. 94-579, § 704(a), 90 Stat. 2743, 2792 (1976). The same provisions repealed a long list of statutes that may have provided the President with the authority to make withdrawals and reservations. Thus, assuming, as argued above, that the President has no inherent constitutional authority to withdraw or revoke withdrawals, these repeals left the President with only the authority newly delegated to him or her under FLPMA $\S 1714$.

377 This is precisely the situation envisioned by Justice Jackson in his famous concurring opinion in Youngstown, where he stated that "[w]hen the President takes measures incompatible with the expressed or implied will of Congress, his power is at its lowest ebb, for then he can rely only upon his own constitutional powers minus any constitutional powers of Congress over the matter." Youngstown Sheet \& Tube Co., 343 U.S. at 637 (Jackson, J., concurring).
} 


\section{Draft: Please do not cite without authors' permission}

To be published at 33 GEO. ENVTL. L. REV., IssuE \# 2

repeal of nonstatutory withdrawal practices cuts even more strongly against recognition of any nonstatutory Executive Branch revocation authority. In the post-FLPMA era, therefore, Presidents can only make, modify, or revoke withdrawals using statutorily derived authority, and in a manner consistent with any restrictions or conditions that Congress placed upon that authority.

\section{B. What Remains: Limited Executive Branch Authority to Make, Modify or Revoke Withdrawals of Federal Lands Under OCSLA and FLPMA}

Throughout much of the nation's history, the allocation of authority to control management of onshore and offshore federal lands and resources has been a bone of contention. The clashes involved conflicting claims of the federal and state governments and a tug of war for control over the uses and fate of federal lands and resources between the executive and legislative branches of the federal government. In adopting FLPMA and OCSLA, Congress clarified the respective realms of authority of the relevant actors, at least with respect to decisionmaking authority over uses of mineral bearing lands. This included the repeal of any vestiges of "inherent," or nonstatutory, presidential authority or practices that impacted prior congressional or presidential withdrawals. ${ }^{378}$ Viewing these two statutes in the context of the history of federal land management, the constitutional provisions governing federal lands, and the evolution of public lands policy to accommodate changing public values sheds light on how Congress sought to organize and cabin Executive Branch authority in FLPMA and OCSLA, particularly concerning efforts to modify or revoke Executive Branch withdrawals from mineral development.

\footnotetext{
${ }^{378}$ See 43 U.S.C. § 1701(a)(4); see also Pub. L. No. 94-579, § 704(a), 90 Stat. 2743, 2792 (1976) (repealing implied presidential and statutorily delegated authority to make withdrawals and reservations).
} 


\section{Draft: Please do not cite without authors' permission}

To be published at 33 GEO. ENVTL. L. REV., IssuE \# 2

The backdrop begins with the Constitution's Property Clause, ${ }^{379}$ which gives Congress plenary power over the federal lands, including the power "to control their occupancy and use, to protect them from trespass and injury, and to prescribe the conditions upon which others may obtain rights in them." ${ }^{380}$ One aspect of this power is the authority to allow or prevent mineral development on federal lands, including on the offshore submerged lands. ${ }^{381}$ Congress can delegate some or all of this Property Clause authority to the President or directly to federal agencies, which it has done in OCSLA, FLPMA, and other public lands statutes, such as the Antiquities Act. ${ }^{382}$ As the district court in the League of Conservation Voters case noted, until Congress delegates to the Executive Branch a power vested in it by the Constitution, its exercise remains the exclusive prerogative of Congress. ${ }^{383}$ When Congress passed OCSLA in 1953, and subsequently amended it in 1978, Congress delegated to the President only the authority to make withdrawals. ${ }^{384}$ It did not delegate the authority to revoke or modify prior withdrawals. Similarly, but with an important caveat, when Congress passed FLPMA in 1976, it reserved to itself the primary authority to make decisions about withdrawals, modifications, and revocations, delegating only specifically limited authority to make, modify, or revoke withdrawals, and then subjected the exercise of that authority to both substantive and procedural conditions. ${ }^{385}$

The proponents of expansive presidential federal land management authority have argued that OCSLA, FLPMA, and the Antiquities Act vest in the Executive Branch statutory authority to modify or revoke prior statutory withdrawals, notwithstanding the limited authority these

\footnotetext{
${ }^{379}$ U.S. CONST. art. IV, $\S 3$, cl. 2.

${ }^{380}$ Kleppe v. New Mexico, 426 U.S. 529, 540 (1976) (internal citations and quotations omitted).

${ }^{381}$ See Duncan Energy Co. v. U.S. Forest Serv., 50 F.3d 584, 589 (8th Cir. 1995) (concerning onshore mineral resources).

38243 U.S.C. $\S \S 1341(a) ; 1714(a) ; 54$ U.S.C. $\S 32301$.

${ }^{383}$ League of Conservation Voters, 363 F. Supp. 3d at 1020.

38443 U.S.C. $\S 1341(\mathrm{a})$.

38543 U.S.C. $§ 1714$ (a) (authorizing the Interior Secretary "to make, modify, extend, or revoke withdrawals but only in accordance with the provisions and limitations of this section"); 43 U.S.C. $\S \S 1714$ (c) \& (e).
} 


\section{Draft: Please do not cite without authors' permission}

To be published at 33 GEO. ENVTL. L. REV., ISSUE \# 2

statutes provide. ${ }^{386}$ The argument is based on the proposition that a statutory delegation of power to take an action carries with it an implied congressional delegation of power (which might be called statutorily derived implicit Executive authority) to undo, or revoke, that action,. ${ }^{387}$

Assessing whether that claim is viable requires careful analysis of the delegations in the relevant statutes to determine whether the authority that the Trump Administration has claimed is outside the scope of the delegated authority, such that its exercise constitutes a usurpation of Congress's Property Clause powers. ${ }^{388}$ FLPMA section 1714 limits the Secretary's discretion to alter the status of a previous withdrawal in several significant ways. Whether these are the only limitations on Executive modification or revocation authority is not entirely clear, however. Section 1714(a) provides that the Secretary "is authorized to make, modify, extend, or revoke withdrawals. . . only in accordance with the provisions and limitations of this section." "389 If the limitations on modification or revocation discussed above ${ }^{390}$ were the only ones Congress intended, it would have made sense in section 1714(a) for Congress to have cross-referenced section 1714(j) (which specifies several limits on Executive authority to make, modify, or revoke withdrawals) explicitly. ${ }^{391}$ Instead, it used the more open-ended language regarding "the provisions and limitations of this section." 392 This reference leaves open the possibility that

\footnotetext{
386 John Yoo \& Todd Gaziano, Presidential Authority to Revoke or Reduce National Monument Designations, 35 YALE J. ON REG. 617, 639 (2018) (arguing that "the authority to execute a discretionary government power usually includes the power to revoke it - unless the original grant expressly limits the power of revocation"). 


\section{Draft: Please do not cite without authors' permission}

To be published at 33 GEO. ENVTL. L. REV., ISSUE \# 2

Congress intended for one or more of the other limitations of section 1714 to apply to the Secretary's authority to modify or revoke prior withdrawals.

One interpretation of section 1714(a) is that the reference to "the provisions and limitations of this section" applies only to the Secretarial power to make (but not to modify or revoke) withdrawals. This interpretation would vest in the Secretary more unconstrained authority to modify or revoke than to make withdrawals. The many requirements reflected in the subsections referred to in section 1714 (a) would apply to withdrawals. ${ }^{393}$ For example, the public and congressional disclosure requirements would apply to withdrawals, providing a measure of transparency ${ }^{394}$ But under this interpretation of section 1714, the Secretary would have nearly unbridled authority to modify or revoke prior withdrawals, without public notice or input, without any need to notify Congress, and without confining the purposes of modifications or withdrawals to those reflected elsewhere in section 1714(a). Under this reading of the statute, the Secretary would be allowed to engage in wholesale, secretive revocations of lands that had previously and publicly been protected for environmental reasons, or to facilitate another of the multiple uses that the President or the Secretary had deemed incompatible with uses such as mineral development. This result flies in the face of the court's recognition of only limited Secretarial revocation authority in the Burford case. ${ }^{395}$ In addition, this interpretation undermines the statutory reference to Secretarial authority "to make, modify, extend, or revoke withdrawals"

\footnotetext{
${ }^{393}$ For example, FLPMA requires that the Secretary provide an opportunity for a public hearing before making any new withdrawals. Id. $\S 1714(\mathrm{~h})$.

${ }^{394}$ FLPMA imposes notification and explanation requirements on the exercise of Secretarial withdrawal authority. See, e.g., id. § 1714(b)(1), (c)(1)-(2), (e)

395 See infra notes 413-419 and accompanying text.
} 


\section{Draft: Please do not cite without authors' permission}

To be published at 33 GEO. ENVTL. L. REV., ISSUE \# 2

which immediately precedes the modifier "consistent with the provisions and limitations of this section." 396

A more sensible reading of section 1714(a) is that Congress intended for the modifier "consistent with the provisions and limitations of this section" to apply to all of the actions that immediately preceded it. That interpretation would support, rather than undermine, FLPMA's policy of ensuring that the public lands be managed in environmentally protective ways. ${ }^{397}$ Moreover, construing section 1714(a) in this manner would support Congress's goals in passing FLPMA of recapturing congressional authority to constrain Executive branch decisions over public land and resource management, consistent with the recommendations of the PLLRC Report. ${ }^{398}$ Thus, both the text and stated purposes of FLPMA support the conclusion that the "limitations" imposed throughout section 1714 were meant to apply to the Executive Branch's discretionary authority the making, modification, or revocation of withdrawals. This reading of section 1714(a) is also consistent with the interpretation of the scope of the Executive Branch's authority to revoke withdrawals provided by the Burford court. ${ }^{399}$

OCSLA's withdrawal provision in section 1341(a), by contrast, is narrower in scope and more succinct, allowing the President "from time to time, to withdraw from disposition any of the unleased lands of the outer continental shelf." ${ }^{400}$ The statute does not delegate authority to modify or revoke withdrawals, although some have argued that a one-way delegation of authority to withdraw (such as the Antiquities Act authority to withdraw lands to create national

\footnotetext{
39643 U.S.C. § 1714(a) (emphasis added); see United States v. Menasche, 348 U.S. 528, 538-39 (1955) (noting the Court's duty "to give effect, if possible, to every clause and word of a statute").

39743 U.S.C. $§ 1701(\mathrm{a})(8)$.

${ }^{398}$ See supra note 288 and accompanying text.

${ }^{399}$ See Nat'l Wildlife Fed'n v. Burford, 835 F.2d 305, 307 (D.C. Cir. 1987). See supra notes 320-328 and accompanying text.

40043 U.S.C. $§ 1341(a)$.
} 


\section{Draft: Please do not cite without authors' permission}

To be published at 33 GEO. ENVTL. L. REV., ISSUE \# 2

monuments) contains an implied delegation of authority to also revoke the withdrawal. ${ }^{401}$ In defense of President Trump's 2017 OCSLA revocation, the government argued that the reference in OCSLA to the authority to withdrawal "from time to time" reflects congressional intent to vest in the President the "power to revise action previously taken under the delegated authority."402 The district court in League of Conservation Voters disposed of this argument through a plain meaning interpretation of the delegation, however, noting that Congress "excluded ... revocation" purposefully. ${ }^{403}$

Both the OCSLA and FLPMA provisions concerning mineral reservations contain ambiguities, as the courts in both Burford and League of Conservation Voters acknowledged. ${ }^{404}$ In both cases, the courts resolved the ambiguities by identifying restrictions on the Executive's authority to engage in withdrawals and modifications or revocations thereof. They construed the two statutes as providing limited delegations to specify appropriate uses of federal lands, and in League of Conservation Voters, the court treated the limited delegation as a reservation by Congress of any Property Clause authority not explicitly delegated to the Executive. ${ }^{405}$ In League of Conservation Voters, the court concluded that the language in section 1341(a) of OCSLA authorizing withdrawals "from time to time" was clearly intended to modify or condition the President's withdrawal authority under OCLSA, but that Congress did not state exactly how it meant to do so. ${ }^{406}$ The court resolved this ambiguity by examining OCSLA's structure and legislative history. It noted that the statute's primary focus in section 1341(a) is "protective,"

\footnotetext{
401 Yoo \& Gaziano, supra note 386.

402 League of Conservation Voters, 363 F. Supp. 3d at 1020.

403 Id. at 1021 .

${ }^{404}$ See supra notes 325, 341-342 and accompanying text.

${ }^{405}$ League of Conservation Voters, 363 F. Supp. 3d at 1020 ("the authority to revoke a prior withdrawal was not delegated by this statute to the President and thus remains vested solely with Congress")

406 The title of this section, "Reservation of Land and Rights," might shed further light on its meaning, demonstrating Congress's desire to recapture its authority over the lands of the outer continental shelf. See Almendarez-Torres v. United States, 523 U.S. 224, 234 (1998) (discussed supra at note 186).
} 


\section{Draft: Please do not cite without authors' permission}

To be published at 33 GEO. ENVTL. L. REV., ISSUE \# 2

aimed at limiting leasing activities on the outer continental shelf. Moreover, the legislative history indicates that when Congress intended to include revocation authority in a statute, it knew how to do so. ${ }^{407}$ It did not provide such authority in OCSLA. In Burford, the court regarded FLPMA section 1714(a)'s revocation authority as ambiguous, looked to other provisions of FLPMA for guidance, and concluded that section 1714 revocations were "management decisions" under section 1712. That conclusion requires the Secretary presumably to comply with section 1712 , at a minimum, whenever making, modifying, or revoking a withdrawal. ${ }^{408}$

The government argued in Burford that FLPMA only requires public participation when the agency promulgates new withdrawals ${ }^{409}$ or implements the statutory land use planning provisions, ${ }^{410}$ but not when it makes revocations. It claimed that withdrawals, modifications, and revocations are governed only by section 1714(a), which imposes no public participation requirements (even though other subsections ${ }^{411}$ of section 1714 do). ${ }^{412}$ The court of appeals was unpersuaded, noting that the legislative history indicated congressional intent to solicit "some form of public input for all decisions that may have significant impact on federal lands," including revocations. ${ }^{413}$ Moreover, the court noted that " $[\mathrm{t}]$ he fact that Congress specifically mandated that a 'hearing' precede new withdrawals does not mean that it did not contemplate some form of public participation, short of a public hearing, in connection with withdrawal

\footnotetext{
${ }^{407}$ League of Conservation Voters, 363 F. Supp. 3d at 1025-27.

${ }^{408}$ Section 1712 of FLPMA provides that the Interior Secretary "may issue management decisions to implement land use plans." 43 U.S.C. $§ 1712$ (e). Those decisions, "including but not limited to exclusions (that is, total elimination) of one or more of the principal or major uses made by a management decision shall remain subject to reconsideration, modification, and termination through revision . . of the land use plan involved.” Id. § 1712(e)(1).

40943 U.S.C. $\S 1714(\mathrm{~h})$.

${ }^{410}$ Id. $\S 1712(\mathrm{a}),(\mathrm{f})$.

${ }^{411} I d . \S 1714(\mathrm{~b})(1),(\mathrm{c}),(\mathrm{h})$.

${ }^{412}$ Nat'l Wildlife Fed'n v. Burford, 835 F.2d at 322.

${ }^{413} I d$. (emphasis added).
} 


\section{Draft: Please do not cite without authors' permission}

To be published at 33 GEO. ENVTL. L. REV., ISSUE \# 2

revocations." ${ }^{414}$ Further still, the court concluded that Congress intended to ensure the opportunity for public participation in connection with all Secretarial "management decisions," and that "withdrawal revocations are themselves major management decisions." 415 In short, the Burford opinion points to a requirement that the Department of Interior develop a "systemic approach to withdrawal revocations," involving the public from start to finish, and provides a basis for invalidating revocations made without these safeguards. ${ }^{416}$

The rationale for the Burford court's recognition of statutory limitations that derive from subsections of section 1714 other than section 1714(j) is not limited to FLPMA's public participation requirements. It also supports the conclusion that statutory notification obligations also attach to Secretarial revocations. Section 1714(b) requires publication of a notice of receipt of an application for withdrawal by the Secretary, or of a withdrawal action proposed by the Secretary, in the Federal Register, giving the public notice and an opportunity to give input on the proposed action through the appropriate channels. ${ }^{417}$ Although section $1714(\mathrm{~b})$ on its face pertains only to withdrawals, it is at least plausible that Congress intended to apply the notification requirement of section 1714(b) to modifications and revocations as well as withdrawals, especially given the absence of any indication in the title to that subsection limiting it (and the notification conditions it imposes on the Secretary) to withdrawals. ${ }^{418}$ This reading would also comport with the Burford court's conclusion that section 1714(a)'s revocation authority is subject to FLPMA's notification and public participation requirements. ${ }^{419}$

${ }^{414} I d$.

${ }^{415}$ Burford, 835 F.2d at 322.

${ }^{416} I d$. at 323.

41743 U.S.C. $\S 1714($ b).

418 See also Almendarez-Torres, 523 U.S. at 234.

419 The court explained the need for those requirements to apply to revocation authority: Permitting the change in status of land from retention (even if for limited purposes) to disposal (even if for limited purposes) raises issues and concerns that are not the same as those that might arise when deciding how or to whom to dispose the land. Evaluating the repercussions of opening 


\section{Draft: Please do not cite without authors' permission}

To be published at 33 GEO. ENVTL. L. REV., IssuE \# 2

In addition to the procedural requirements discussed immediately above, the Ninth Circuit in National Mining Association concluded that FLPMA section 1714 is somewhat ambiguous even with respect to the withdrawal authority it delegates to the Secretary. Although the court in that case was not directly considering Executive revocation authority, the reasoning it used to conclude that section 1714(a) withdrawal authority must be consistent with the provisions of sections 1701 (enunciating FLMPA's purposes) and 1702 (setting forth key statutory definitions) supports the conclusion that revocation authority is subject to the same requirement. Thus, for example, a Secretarial decision to revoke a withdrawal under 1714(a) must be consistent with the public values, and be undertaken for a public purpose, recognized by Congress in section 1701(8).

In brief, the delegations in OCSLA and FLPMA are limited grants of authority to either the President (OCSLA) or the Secretary of Interior (FLPMA). OCSLA's grant of authority is only to make withdrawals, and for only the purposes outlined in that statute OCSLA does not permit the exercise of implied authority to modify or revoke prior withdrawals. The delegations to the Interior Secretary in FLPMA are broader, in the sense that they delegate authority to "make, modify or revoke" withdrawals, but the statute carefully circumscribes the exercise of that delegated authority. The Secretary cannot modify or revoke withdrawals of any size and for any reason. Secretarial decisions to make, modify and revoke withdrawals must comport with the size and temporal limitations outlined in section 1714(a), be undertaken for purposes consistent

millions of acres to potential development entails different and graver considerations than judgments concerning the local impact and advisability of uses for particular parcels. The patchwork of provision for public comment on specific disposals cannot adequately substitute for public input into this important aspect of comprehensive planning. In addition, the discretionary nature of these public participation requirements dictates that many individual land disposal decisions will never be subject to meaningful public scrutiny. $\underline{I d}$. at 323 . 


\section{Draft: Please do not cite without authors' permission}

To be published at 33 GEO. ENVTL. L. REV., ISSUE \# 2

with statutory purposes, comply with the procedural requirements of notice and opportunity to comment, and be consistent with the land use planning process that FLPMA created for the management of the federal lands managed by the Interior Department.

\section{CONCLUSION}

The Trump Administration's withdrawal modifications and revocations pursuant to its America First Energy Plan raise important issues for which there is limited judicial precedent. In particular, judicial analysis of the scope of Executive branch authority to make, modify, and revoke withdrawals from mineral development based on authority provided by OCSLA or FLPMA is sparse or nonexistent. The litigation thus far over this issue in the League of Conservation Voters and National Mining Association cases is revealing, even if not yet dispositive. ${ }^{420}$ The litigation raising ultra vires challenges to President Trump's reduction of the two Utah national monuments created by Presidents Clinton and Obama might shed some further light, by analogy, on the question of whether the power to withdraw includes or excludes the power to revoke a withdrawal, even though that litigation involves the Antiquities Act, not OCSLA or FLPMA. ${ }^{421}$

Although President Trump may have regarded revocations of withdrawals made by previous administrations as a quick and effective way to open up vast new acreage to mineral development, the legal basis for these actions is tenuous at best. ${ }^{422}$ The Alaska district court has halted President Trump's effort to reopen waters off the Alaskan and Atlantic coasts to mineral development that President Obama had prohibited. That forceful rebuke hearkens back to the

\footnotetext{
${ }^{420}$ The district court's decision in League of Conservation Voters has been appealed to the Ninth Circuit. League of

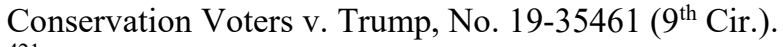

${ }^{421}$ The Antiquities Act delegation of authority to withdraw qualifying objects and surrounding lands as a national monument is most similar to OCSLA's one-way delegation of authority to withdraw offshore submerged lands. ${ }^{422}$ League of Conservation Voters, 363 F. Supp. 3d at 1031.
} 


\section{Draft: Please do not cite without authors' permission}

To be published at 33 GEO. ENVTL. L. REV., IssuE \# 2

judicial responses to similar actions during the first term of the Reagan Administration in cases such as National Wildlife Federation v. Burford. In response to those Reagan Administration actions, the courts reviewing them also halted the unlawful Executive Branch actions, finding them to be beyond the scope of the management authority delegated to the Executive Branch under FLPMA. ${ }^{423}$ Although Burford did not address the scope of presidential withdrawal revocation authority under FLPMA, its analysis supports recognition of significant restrictions on that authority.

The Trump Administration has been determined to promote its energy dominance/energy first agenda on the public lands as well as on the outer continental shelf. Most recently, in June 2020, the Department of Interior released the final environmental impact statement and record of decision for the National Petroleum Reserve in Alaska, opening up $82 \%$ of the 23 million acre reserve to drilling. ${ }^{424}$ The Department has also revoked dozens of withdrawals on the BLM public lands between 2017 and 2020, ${ }^{425}$ and the Forest Service has recommended cancellation of the Grand Canyon mineral withdrawals at issue in National Mining Association v. Zinke (although the agency has not yet taken meaningful action following this recommendation). ${ }^{426}$

\footnotetext{
${ }^{423}$ See supra note 324 and accompanying text.

${ }^{424}$ Tegan Hanlon, Trump Administration Wants to Open Millions of More Acres to Oil Development on Alaska's North Slope, AlaSKa PUBlic Media (June 26, 2020), https://www.alaskapublic.org/2020/06/26/trumpadministration-wants-to-open-millions-of-more-acres-to-oil-development-on-alaskas-north-slope/. ${ }_{425}$ See, e.g., Public Land Order 7888, Partial Revocation of Secretarial Order dated Dec. 22, 1928, 84 Fed. Reg. 66433 (Dec. 4, 2019) (opening 21 acres of public lands in New Mexico to mineral leasing); Public Land Order 7881, Partial Revocation, Jupiter Inlet Lighthouse Withdrawal, 84 Fed. Reg. 37334 (July 31, 2019) (opening 16 acres of submerged lands to mineral leasing); Public Land Order 7879, Partial Revocation of Public Land Orders No. 5173, 5178, 5179, 5180, 5184, 5186 and 5187, 84 Fed. Reg. 32946 (July 10, 2019) (opening 1.1 million acres of public lands in Alaska to mineral leasing).

${ }^{426}$ Emery Cowan, Forest Service Recommends Modifying Uranium Mining Ban Near Grand Canyon, ARIz. DAILY Sun, Nov. 2, 2017, https://azdailysun.com/news/local/forest-service-recommends-modifying-uranium-mining-bannear-grand-canyon/article 40f832ed-55ae-5c43-885c-c96fed0c1e48.html. The Commerce Department's endorsement of improved access to domestic "critical mineral" resources, including uranium, on federal lands increases the prospects for termination of these withdrawals. See U.S. DEP'T OF COMMERCE, A FEDERAL STRATEGY to EnSURE SECURE AND RELIABle SuPPLIES OF CRITICAL Minerals 37 (June 2019), https://www.commerce.gov/news/reports/2019/06/federal-strategy-ensure-secure-and-reliable-supplies-criticalminerals\#_ftn1; Exec. Order No. 13817, A Federal Strategy to Ensure Secure and Reliable Supplies of Critical
} 


\section{Draft: Please do not cite without authors' permission}

To be published at 33 Geo. EnVtL. L. ReV., ISSUE \# 2

Thus far, the Administration's onshore revocations have paled in comparison to its attempted offshore revocations, but if past is prologue, there may be more to come.

Although the provisions of OCSLA and FLPMA bearing on withdrawals (and revocations) differ, courts have interpreted the provisions of both statutes in the context of the overarching statutory purposes and structures, as well as in light of the FLPMA's environmental quality and resource protection policies, rather exclusively than through a narrow textual lens. ${ }^{427}$ In adopting FLPMA and OCSCLA, Congress sought to reign in Executive branch authority to make, modify, and revoke withdrawals in light of modern federal retention and conservation policies. Consistent with this priority, the courts have rightly interpreted Executive Branch withdrawal authority more expansively than its discretion to revoke withdrawals aimed at protecting federal lands against destructive mineral development. The Trump Administration's efforts to accelerate mineral development by reversing previous withdrawals taken to protect

Minerals, § 2(a) 82 Fed. Reg. 60835 (Dec. 26, 2017) (defining a "critical mineral" as one that is "essential to the economic and national security of the United States").

FLPMA only delegates withdrawal authority to the Interior Secretary, not the Secretary of Agriculture, which houses the U.S. Forest Service. The BLM is responsible for minerals management in both the national forests and the public lands. As a result, the BLM, not the Forest Service, has the authority to make (or revoke) withdrawals in the national forests for the purpose of reopening those lands to mineral development. See Nat'l Mining Ass'n, 877 F.3d at 878 (stating that Congress "decidedly did not confer on the Forest Service (or the Department of Agriculture) the power independently to open or close federal lands to mining"). FLPMA, however, conditions the Interior Secretary's authority to make, modify, or revoke withdrawals on lands managed by another agency (including the national forest) on the consent of the Secretary of the surface management agency. 43 U.S.C. $§ 1714(l)$. According to the Ninth Circuit, "Congress may have included the consent requirement within FLPMA in part to ensure that Interior would account for significant above-ground impacts on lands managed by the Forest Service, or to forestall interagency squabbling concerning jurisdiction over withdrawn lands." Nat'l Mining Ass'n, 877 F.3d at 878. Cf. S.E. Conf. v. Vilsack, 684 F. Supp. 2d 135, 144-45 (D.D.C. 2010) (holding that land use designations under Forest Service land and resource management plans are not "withdrawals," even if their practical effect is to close the affected area to timber harvests).

${ }^{427}$ The Supreme Court has pursued a similar approach, at least on occasion, in the face of statutory ambiguity. See, e.g., King v. Burwell, 135 S. Ct. 2480, 2489 (2015) ("If the statutory language is plain, we must enforce it according to its terms. But oftentimes the meaning — or ambiguity — of certain words or phrases may only become evident when placed in context.") (internal citations and quotations omitted). $C f$. County of Maui, Hawaii v. Hawaii Wildlife 140 S. Ct. 1462 (2020) (relying on the structure and purposes of the Clean Water Act in determining when the statute's prohibition on unpermitted discharges applies to discharges to groundwater). 
Draft: Please do not cite without authors' permission

To be published at 33 GEO. ENVTL. L. REV., IsSUE \# 2

environmental values and resources in the face of contrary history and precedent deserve a similar fate. 